This is the final author copy of the peer reviewed accepted version of the following article: Brighenti S, Tolotti M, Wharton G, Bertoldi W, Bruno MC (accepted 11.11.20) Rock glaciers and paraglacial features influence stream invertebrates in a deglaciating Alpine areas, Freshwater Biology, which has been published in final form at DOI:10.1111/fwb.13658. This article may be used for non-commercial purposes in accordance with Wiley Terms and Conditions for Self-Archiving.

\title{
Rock glaciers and paraglacial features influence stream invertebrates in a deglaciating Alpine area
}

STEFANO BRIGHENTI ${ }^{1,2,3,4}{ }^{*}$, MONICA TOLOTTI ${ }^{3}$, WALTER BERTOLDI ${ }^{2}$, GERALDENE WHARTON ${ }^{4}$, MARIA CRISTINA $B R U N O^{3}$

${ }^{1}$ Faculty of Science and Technology, Free University of Bolzano/Bozen, Bolzano, Italy

2 Department of Civil, Environmental and Mechanical Engineering, University of Trento, Trento, Italy

${ }^{3}$ Department of Sustainable Agro-ecosystems and Bioresources, Research and Innovation Centre, Fondazione Edmund Mach, San Michele all'Adige, Italy

${ }^{4}$ School of Geography, Queen Mary University of London, London, United Kingdom

*Corresponding Author: Stefano Brighenti, Faculty of Science and Technology, Free University of Bolzano/Bozen. Piazza Università 5, 39100, Bolzano, Italy. +39 3474806941. stefano.brighenti@alumni.unitn.it

Running title: Rock glaciers influence stream invertebrates

Keywords: alpine streams, deglaciation, invertebrate biomass, stepping-stones, climate refugia 


\section{SUMMARY}

1. Climate change and progressive glacier loss are leading to rapid ecological shifts in alpine river networks. Rock glaciers and paraglacial features such as proglacial lakes, moraines, and taluses can alter the gradients of glacial influence along alpine river networks, but the ecological responses are still understudied.

2. We investigated benthic invertebrate communities of different stream types (upper kryal, lower kryal, glacio-rhithral, krenal, and rock glacial) within a deglaciating area of the Italian Alps (Solda and Zay subcatchments). Alpha (Shannon index and taxa richness) and beta diversity (i.e., nestedness and turnover), production (abundance, biomass), average body mass of invertebrate taxa, and functional feeding groups were used to analyse the influence of habitat conditions on invertebrate communities in different microhabitats (mineral substrates, bryophytes, Hydrurus foetidus). We defined an "index of habitat mildness" based on water temperature, channel stability, turbidity, and organic detritus, to measure the difference in community metrics over a gradient of habitat amelioration, driven by the mixing of distinct stream types and their interactions with paraglacial features.

3. While diversity proxies showed an asymptotic behaviour along the gradient, the quantitative metrics peaked at intermediate mildness. Peaks of invertebrate biomass/abundance were recorded at the glaciorhithral station below the talus. Highest average body mass occurred at Zay, specifically at the rock glacial stream, and at the lower kryal stations influenced by the lake/moraine and the rock glacier. The moraine outflow showed unexpected high biomass/abundance values of shredders and grazers, that were supported by a high epilithic production. Bryophytes acted as local scale multipliers of mildness as they stored more detritus, and hosted higher biomass/abundance of invertebrates and, in particular, of gatherer-collectors.

4. Beta diversity, driven by the turnover component, was positively related to different habitat mildness of the sampling stations. Although influenced by distinct lentic/lotic conditions, rock glacial streams hosted several taxa typical of glacio-rhithral and krenal stations, alongside large numbers of Diamesa (Chironomidae), a genus typical of kryal habitats.

5. Under progressive deglaciation, rock glaciers and paraglacial features influence the invertebrate communities of alpine river networks. As they host a high number of taxa dwelling in non-glacial locations, rock glacial streams may act as "stepping stones" facilitating invertebrate colonisation following glacier retreat. After glacier loss, rock glacial streams may represent "climate refugia" for cold adapted taxa and/or kryal specialists, because the slow thawing of their ice might sustain cold water conditions for a longer period of time. 


\section{INTRODUCTION}

Climate change and consequent deglaciation are leading to rapid shifts in mountain ecosystems (Intergovernmental Panel on Climate Change [IPCC], 2019) such as alpine streams (Huss et al., 2017; Brighenti et al., 2019a). The anticipation of the snowmelt period and the declining hydrological contribution from glaciers are paralleled by an increased likelihood of water shortages and flow intermittency driven by stochastic precipitation patterns, and by a greater hydroecological contribution from groundwater and thawing permafrost (Milner, Brown \& Hannah, 2009; Brighenti et al., 2019a). Outflows from rock glaciers, i.e., creeping rocky debris containing permafrost ice (Jones, Harrison, Anderson \& Whalley, 2019), have been recently proposed as a particular habitat (Hotaling et al., 2019; Brighenti et al., 2019b), given the unique environmental conditions that include clear $(<5 \mathrm{NTU})$ and cold $\left(<1.5^{\circ} \mathrm{C}\right)$ waters, stable channels, and high concentrations of major ions and trace elements (Colombo et al., 2018). Despite contributing to the hydrological diversity of alpine river networks, rock glacial streams have hitherto received little attention from ecological research on benthic invertebrates, when compared to glacier-fed (kryal) and groundwater-fed (krenal) systems (Brighenti et al., 2019a).

Glacier retreat promotes the upstream dispersal of downstream taxa, with the ultimate extinction of kryal specialists, homogenisation of stream communities (e.g., Hotaling, Finn, Giersch, Weisrock \& Jacobsen, 2017; Milner et al., 2017), and modifications in the functional performance of organisms and ecosystem processes (Brown et al., 2018). As the glacial influence decreases (in space and/or time) during the snow free season, the resulting habitat amelioration associated with increasing water temperature and clarity, abundance of organic detritus, and channel stability, promotes the substitution of kryal specialists with more generalist taxa, and an overall increase of invertebrate diversity and production (e.g., Lencioni, 2018). While the influence of proglacial lakes on these ecological patterns along the glacier-fed river continuum has been well studied (e.g., Milner \& Petts, 1994; Milner, Brittain, Castella \& Petts, 2001; Hieber, Robinson, Uehlinger \& Ward, 2005, Finn, Rasanen \& Robinson, 2010), little is known on the ecological relevance of other paraglacial features (i.e., occurring following glacier retreat) such as moraines and taluses, although these landforms have been shown to decrease the glacial influence along the glacier-fed streams (Brighenti et al., 2019b). The pattern of glacial influence is also mediated by local conditions such as mesohabitat diversity and riffle-pool prevalence, which influences the invertebrate communities and their functional traits over small spatial scales (Herbst, Cooper, Medhurst, Wiseman \& Hunsaker, 2018). Bryophyte mats boost organic detritus retention and invertebrate production (Stream Bryophyte Group [SBG], 1999), but their ecological role is overlooked in alpine streams (Suren, 1991). Bryophytes are generally absent in kryal systems but they can colonise new reaches when the fading glacial influence enhances the stability of the channel (Milner et al., 2017). High-elevation springs, such as those fed by rock glaciers, typically host extensive mats of bryophytes (Brighenti et al., 2019b), and provide additional sources for their dispersal (SBG, 1999) as deglaciation proceeds.

This study aimed to understand the patterns of stream invertebrate communities in a deglaciating catchment of the European Alps. In particular, we hypothesised that: H1) bryophyte mats, where present, store more organic detritus and host greater invertebrate abundance and biomass than mineral substrates; $\mathrm{H} 2$ ) as rock glaciers and paraglacial features promote the amelioration of the physical habitat (Brighenti et al., 
2019b), they enhance invertebrate abundance, biomass, body size, and diversity along the river continuum; H3) the large riverscape diversity enhanced by different water sources promotes a high species turnover, which is in turn correlated with differences in habitat mildness; $\mathrm{H} 4$ ) because of their particular habitat conditions, rock glacial streams host communities typical of non-glacial streams (i.e., krenal, glacio-rhithral), besides the abundance of taxa typical of kryal habitats.

\section{METHODS}

\subsection{Study area}

The Solda Valley (South Tyrol, Italy) is located in the European Alps and hosts several glaciers undergoing rapid recession (World Glacier Monitoring Service [WGMS], 2018), rock glaciers, moraine deposits, taluses, and tills (Montrasio et al., 2015; Autonomous Province of Bolzano/Bozen [APB], 2018). A set of sampling stations (Figure 1, Table 1) underlain by metamorphic bedrock (primarily orthogneisses and quartzphyllytes) was selected in the Zay (Z) and Solda (S) subcatchments, to represent distinct stream types according to their origin and distance from the glacier. The two upper kryal stations along the Zay Stream $(Z 1, Z 3)$ are separated from the lower kryal ones by a proglacial lake and a subterranean reach across a moraine deposit. The moraine outflow (Z4) flows parallel to a rock glacier, whose lentic outflow (ZRG) converges with the Zay Stream in a glacial floodplain (Z5). From there, the stream seeps into a talus that separates the lower kryal and glaciorhithral sections. These include the talus outflow $(\mathrm{Z7})$ in the alpine belt, and a reach in the subalpine belt (Z12) close to the subcatchment's closing section (Figure 1B; Table 1). The remaining stations were two krenal sites (SKN, ZKN) located in the subalpine belt, and two upper kryal reaches (S1, S2) and one rock glacial stream (SRG) in the nival belt (Figure 1C; Table 1). The habitat conditions of the Zay Stream are strongly influenced by the presence of the lake and the moraine (Brighenti et al., 2019b). As a result, the lower kryal sections are characterized by lower turbidity and higher channel stability than the upper kryal stations (Table 1). The rock glacial stream (ZRG) strongly influences the hydrochemistry of the entire Zay Stream below the confluence, especially during autumn, when the glacial influence is low and permafrost influence is high (Brighenti et al., 2019b). Bryophyte mats are absent in the upper kryal stations except Z3, where they cover < $5 \%$ of the streambed. In contrast, they are particularly abundant at the moraine (Z5) and talus outflows (Z7), and at SRG (35-50\% coverage; Table 1).

\subsection{Field activities}

The selected stations were investigated over two consecutive years $(2017,2018)$ in the same periods of the alpine summer (late June, early August, and early September). The habitat conditions of the sampling stations (Table 1) are described in Brighenti et al. (2019b).

The organic content and Chl-a concentration of epilithic biofilm were estimated on two sets of cobbles (three to five, depending on the biofilm thickness), that were randomly chosen from the permanently wet streambed. Each cobble was delimited by a plastic frame and brushed with a toothbrush (total area for each set: $4-117 \mathrm{~cm}^{-2}$, depending on the biofilm thickness). The toothbrush was then washed in a polypropylene vial filled with deionized water, and the rinse from each set of cobbles was in turn filtered in the field through pre- 
weighted GF/C Whatman glass filters with a portable vacuum pump (Mityvac MV8030, USA). Filters were frozen $\left(-20^{\circ} \mathrm{C}\right)$ within 4 hours of collection and transported to the laboratory in thermal bags.

Zoobenthos was collected with a Surber sampler (mesh size $100 \mu \mathrm{m}, 506 \mathrm{~cm}^{2}$ area). For each station, we identified a stream reach (length $\sim 15-50$ m depending on the channel width), where we estimated the extent of different organic (bryophyte mats, Hydrurus foetidus) and mineral (sand, gravel, cobbles, boulders; size limits according to Krumbein, 1934) microhabitats. Five Surber replicates in total were collected from these microhabitats according to their relative abundance in the channel (total area investigated: $0.25 \mathrm{~m}^{2}$ ). Mineral substrates were manually disturbed following Merritt, Resh \& Cummins (1996), whereas H. foetidus and bryophytes were repeatedly shaken and rubbed underwater to detach most of the organisms living within them. Bryophyte fragments were subsequently rinsed in a tray of water, and discarded afterwards, to collect mostly the associated detritus and invertebrates. Samples from mineral substrates (pooled together), bryophyte mats, and $H$. foetidus were collected separately in bottles filled with $95 \%$ ethanol after filtering (100 $\mu \mathrm{m}$ mesh size filters).

\subsection{Laboratory analyses}

For the assessment of epilithic Chl- $a$, the first set of filters were shredded and extracted overnight in $90 \%$ acetone. The extracts were filtered through GF/F Whatman glass filters and analysed with a spectrophotometer following Steinmann, Lamberti \& Leavitt (1996). The second set of filters was oven-dried (1 $\left.\mathrm{hr}, 110^{\circ} \mathrm{C}\right)$ and ashed $\left(1 \mathrm{hr}, 550^{\circ} \mathrm{C}\right)$ for the assessment of the organic content $\left(\mathrm{g} \mathrm{m}^{-2}\right)$ following Steinmann et al. (1996).

Invertebrates and bryophyte fragments were sorted under a dissecting stereomicroscope (Motic SMZ-168, Leika MZ-12-5), and the remaining detritus was filtered with a $1 \mathrm{~mm}$ mesh sieve to separate coarse (CPOM) and fine (FPOM) particulate organic matter fractions. For each sample, CPOM and FPOM were placed in aluminium vials and dried in the oven $\left(60^{\circ} \mathrm{C},>48 \mathrm{~h}\right)$. After weighing, detritus was ashed in a furnace $\left(550^{\circ} \mathrm{C}\right)$ for 4 hours and reweighed. The benthic organic matter (BOM) was then calculated as AFDM ( $\mathrm{g} \mathrm{m}^{-2}$ ), resulting in the combination of CPOM ( $\geq 1 \mathrm{~mm}$ ) and FPOM $(<1 \mathrm{~mm})$. H. foetidus was processed without any further treatment, given the practical limitations in separating detritus from algal filaments. Benthic invertebrates were determined at the levels of species (Plecoptera, Ephemeroptera, Trichoptera, with the exception of early larval stages, which could not be identified at this taxonomic level), genus (Mollusca, Chironomidae subfamily Diamesinae), subfamily (other Chironomidae), family (other Diptera, Oligochaeta) or order (Copepoda, Hydrachnidia, Ostracoda, Tardigrada, Nematoda) by using a stereomicroscope (Leika MZ-12-5) and a light microscope (Leica DC-300F) and following the available dichotomic keys and identification manuals (Consiglio, 1980; Belfiore, 1983; Campaioli, Ghetti, Minelli \& Ruffo, 1994; 1999; Lencioni, Marziali \& Rossaro, 2007; Waringer \& Graf, 2011). The body length of each specimen was measured under the stereomicroscope following Méthot et al. (2012), using $0.5 \mathrm{~mm}$ precision graph paper.

The invertebrate community metrics were characterised for each station in all three summer periods of 2017 resulting in a total of 49 samples; 22 supplementary samples collected in 2018 were analysed to assess 
interannual variability at key stations, and to complete the dataset for Z1 (not accessible in June 2017), Z4 (added in August 2017), and Z12 (added in 2018).

\subsection{Data analysis}

To summarize the habitat amelioration as a function of the key environmental conditions, we produced an "Index of Habitat Mildness (IHM)", following an approach similar to the one previously used to develop a glacial index (as modified by Brighenti et al., 2019b from Ilg \& Castella, 2006). First, we performed a PCA using the following variables: $T_{\text {avg }}$ (average water temperature measured for the week before the sampling date), BOM, 1/turbidity, 1/PFAN bot (bottom component of the Pfankuch index; Pfankuch, 1975). Secondly, we rescaled the sample scores on PC1 to positive numbers to obtain the values of the index (see Brighenti et al., 2019b for further details). For BOM, we applied conversions when comparing different microhabitats, accounting for the abundance of bryophyte fragments trapped in the cobbles (Supplementary S1). To calculate the biomass of invertebrates, we applied size-mass exponential equations $\left(D M=a * L^{b}\right.$, were $a$ and $b$ are taxon-specific constants) to estimate the dry mass $\left(\mathrm{g} \mathrm{m}^{-2}\right.$ ) of each genus (for Ephemeroptera, Plecoptera, Trichoptera: EPT) or family (for Diptera and Oligochaeta) in each sample, following the most accurate estimates for each taxon (see Supplementary S2). Pupae and meiofaunal taxa (i.e., Hydrachnidia, Copepoda, Nematoda, Tardigrada, Ostracoda) were excluded from this specific analysis. The total biomass for each taxon, sampling station, date, and microhabitat was estimated by adding together the body mass of all individuals in the sample. Average "taxon body mass" was estimated by applying size-mass equations (Supplementary S2) to the mean size of each taxon. The "average body mass" in the sample was calculated as the weighted mean of the average taxa body masses, i.e., accounting for the abundance of each taxon in the community.

The abundance and biomass of functional feeding groups were estimated by following a procedure accounting for the feeding plasticity of alpine stream invertebrates (e.g., Niedrist \& Füreder, 2017; Füreder \& Niedrist, 2020). The European database for freshwater organisms (www.freshwater.org) assigns each species a score (0-10) based on its affinity to a particular "feeding type" (Functional Feeding Group - FFG in our study). We assigned each identified taxon to a particular FFG only if it was scored $\geq 5$ in the database (i.e., if high affinity). Early stages of Plecoptera were all attributed to gatherer-collectors, and Diamesa in kryal stations to grazers (Niedrist et al., 2018).

Invertebrate diversity was assessed by calculating richness (i.e., total number of taxa, standardized with rarefaction to account for the differences in sample size) and the Shannon index, using the package vegan (Oksanen et al., 2018) in R (R Core Team, 2017). Stream communities were analysed with a non-metric multidimensional scaling (NMDS) in vegan, based on a Bray-Curtis distance matrix calculated from $\log (\mathrm{x}+1)$ transformed taxa abundances. We ensured the convergence of solutions at a stress value $<0.2$. We used the NMDS Shepard plot to check for strong correlation between the interpoint distances in the original versus the final configuration of dissimilarities in the bidimensional space. We calculated the Spearman rank correlation coefficients between $\log (x+1)$-transformed taxa abundances and the NMDS sample scores on the first two NMDS axes to identify the most important taxa driving the NMDS configuration. We performed an analysis of 
similarity (ANOSIM; Clarke, 1993) to test for significant differences in community composition between stations and stream types, using the function adonis from package vegan.

We assessed beta diversity patterns with the package betapart (Baselga, Orme, Villeger, DeBortoli \& Leprieur, 2017) by conducting the analyses of multiple-site dissimilarity. After pooling together the presence/absence data of the different sampling dates for each station, we calculated the total beta diversity based on the Sørensen index ( $\beta$ SOR), and its two components, i.e., taxa turnover based on Simpson index ( $\beta$ sIM) and nestedness $\left(\beta_{S N E}=\beta_{S O R}-\beta_{S I M}\right)$. Therefore, we obtained dissimilarity matrices based on pairwise beta

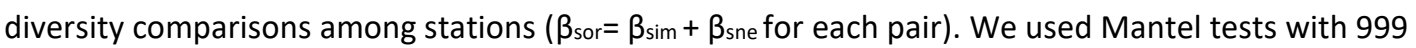
permutations (Anderson et al., 2011) to estimate the correlation between matrices of beta diversity ( $\beta_{\text {sor, }} \beta_{\text {sim }}$

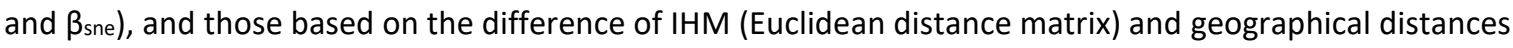
(based on APB, 2018) between stations.

We performed pairwise comparisons with the software SPSS (v.26, IBM, 2018) to analyse differences in environmental and community variables between groups defined by the following factors: sampling month (June, August, September), stream type (upper kryal, lower kryal, glacio-rhithral, krenal, rock glacial), and microhabitat (mineral substrates, bryophyte mats, $H$. foetidus; samples with only one microhabitat excluded from these pairwise comparisons). Due to non-normal data distribution (Shapiro-Wilk test, $\mathrm{P}<0.05$ ), and/or inhomogeneous variances (Levene test, $\mathrm{P}>0.05$ ) between groups, persisting even after transformation, we used non-parametric Mann-Whitney (two groups) or Kruskal-Wallis (> two groups) tests, with post-hoc Bonferroni correction applied to control Type-I error.

Linear Mixed-Effects Models (LMM) were performed using the Ime4 R package (Bates, Maechler \& Bolker, 2012) to assess the importance of different fixed factors (i.e., stream type, microhabitat, month) in regulating the amount of detritus and the community metrics, while accounting for the effects of random factors (i.e., station, taxon). Plots of residuals were inspected to ensure their homoscedasticity and normality, and variables were $\log (x+1)$-transformed when these criteria were not satisfied. To test for statistical significance, we calculated the p-values by running likelihood ratio of the "full model" with the effect in question tested against the model without the effect in question ("null model"), including the same random structure (Supplementary S3). Patterns of community metrics as a function of the IHM were described with Generalized Additive Models (GAM) with the mgcv package (Wood, 2006). Akaike's information criterion (AIC) was used for the selection of Gaussian, Poisson, Negative binomial, and Gamma distribution (Zuur et al., 2009).

\section{RESULTS}

The first axis of the PCA (performed to build the IHM) explained $54.6 \%$ of the total variance within the dataset, and was significantly correlated $(p<0.01)$ with all the included variables: BOM $(r=0.90), 1 /$ PFANbot $(r=0.78)$, $1 /$ turbidity $(r=0.69)$, and $T_{\text {avg }}(r=0.55)$. IHM values were lowest in the upper kryal, intermediate in lower kryal, and highest for glacio-rhithral and krenal stations. The glacio-rhithral stations had IHM values similar to those of SRG, and the lower kryal stations to those of ZRG (Figure 2A).

\subsection{Biotic habitat conditions}


Organic content of epilithic biofilms did not differ significantly among stream types but we recorded significantly lower $\mathrm{Chl}-a$ concentrations per unit area (multiple pairwise comparisons: $\mathrm{H} \geq 20.5, \mathrm{p} \leq 0.023$ ) in the upper kryal compared to the other stream types, with the latter not significantly differing from each other (Table 1). Values of epilithic Chl- $a$ and organic content were higher in the lower kryal stations (i.e., below the moraine and the junction with the Zay rock glacial stream) than in the other stream types (Table 1).

BOM was lower in the upper kryal stations, increased when moving to lower kryal, glacio-rhithral, and krenal habitats, and had intermediate values at rock glacial stations (Table 1). Where present in the channel, bryophyte mats stored significantly higher BOM than the mineral substrates $(U=329, p<0.001)$, even though the stream type was a significant mediator of this difference (Figure 3; Supplementary S3 for LMM results).

\subsection{Diversity metrics and community composition}

Taxa richness (with rarefaction) and Shannon index differed significantly among stream types ( $H=35.7, p<$ 0.001 and $\mathrm{H}=21.2, \mathrm{p}<0.001$, respectively), and grew asymptotically along the IHM gradient, with peaks corresponding to SRG, Z12, and krenal stations (Figures 2A-C, 4; Tables 1,2). Rock glacial habitat had significantly higher diversity and richness $(U=11.3, p=0.001$ and $U=10.7, p=0.001$, respectively) than the upper kryal. SRG had significantly higher richness than ZRG $(U=5.4, p=0.02)$, and a Shannon index among the highest in the catchment, comparable to krenal and glacio-rhithral stations. In contrast, these indices were comparable for ZRG and the lower kryal stations (Figure 2B-C, Table 1). Taxa richness $(U=230, p=0.34$ ) and diversity $(U=227, p=0.31)$ did not differ significantly between bryophyte mats and mineral substrates (Figure 2B-C).

Overall beta diversity ( $\beta_{S O R}=0.76$ ) was partitioned in $58 \%$ taxa turnover $\left(\beta_{S I M}=0.44\right)$ and $42 \%$ nestedness $\left(\beta_{\mathrm{SNE}}=0.32\right)$. The largest beta diversity $\left(\beta_{\mathrm{Sor}}>0.5\right)$ was detected between the upper kryal and the group of glacio-rhithral and krenal stations, and was mostly driven by its nestedness component ( $\beta_{\text {sne }}>80 \%$ ). The lowest beta diversity was mostly driven by turnover ( $\beta_{\text {sim }}>82 \%$ ), and was detected among krenal $\left(\beta_{\text {sor }}=0.2\right)$ and among glacio-rhithral $\left(\beta_{\text {sor }}=0.3\right.$ ) stations, and between SRG and the group of krenal, lower kryal, and Z7 stations (all $\beta_{\text {sor }}=0.3$ ). Beta diversity between the two rock glacial stations had intermediate values $\left(\beta_{\text {sor }}=0.4\right)$ and it was mostly driven by nestedness ( $\beta_{\text {nes }}=67 \%$ ). Pairwise differences in $\mathrm{HM}$ were significantly and positively correlated with $\beta_{\text {sor }}$ (Mantel test: $\left.r=0.51, p=0.004\right)$ and $\beta_{\text {sne }}(r=0.50, p=0.005)$, but not with $\beta_{\text {sim }}(r=-$ $0.32, p=0.97)$. The geographical distance between stations was not significantly correlated to all beta diversity metrics ( $p \geq 0.32$ ).

The NMDS plot (Figure 5) showed a separation of communities according to the habitat type (stress value= $0.12, R^{2}=0.99$ in the Shepard plot). The ANOSIM analysis confirmed significant differences among stations ( $R=$ $0.82, p=0.001)$ and among stream types $(R=0.59, p=0.001)$. We identified three clusters of stations characterized by different community composition in the NMDS space, with several taxa contributing to the grouping along the first two NMDS axes (Table 3). A first cluster comprised the upper kryal stations, where Chironomidae of the genus Diamesa ( $>80 \%$ of invertebrates) outnumbered the Orthocladiinae and meiofaunal taxa. Although not detectable in the NMDS space, Diamesa was the dominant Chironomidae taxon also at the lower kryal habitats (61-83\%; average for $Z 5$ and Z4, respectively). This genus was relatively abundant in rock 
glacial stations (12-16\%, SRG and ZRG), and infrequent in the glacio-rhithral (0-3\%, Z12 and Z7) and krenal (0$2 \%, S K N, Z K N)$ stations. A second cluster in the NMDS space included the lower kryal stations and ZRG, both characterized by relatively high abundance of the genus Pseudodiamesa (Chironomidae Diamesinae), Copepoda (mainly Cyclopoida), Nematoda, and Haplotaxidae when compared with the other groups. These stations also hosted Chironomidae Orthocladiinae (the dominant Chironomidae subfamily at ZRG), other Diptera (Muscidae, Tipulidae, Simuliidae), Acrophylax zerberus (Trichoptera), and Baetis alpinus (Ephemeroptera), Dictyogenus fontium, Protonemura spp (Plecoptera) and Drusus cf. adustus (Trichoptera) at the station below the rock glacial stream (Z5). The third cluster in the NMDS space comprised SRG, glaciorhithral, and krenal stations characterized by abundant EPT and Diptera. At SRG, the abundance and diversity of Plecoptera (D. fontium, Isoperla rivulorum, Leuctra rosinae, Nemoura mortoni, Rhabdiopteryx alpina), Ephemeroptera (B. alpinus, Rhithrogena loyolaea) and Trichoptera (Drusus monticola, D. adustus) were comparable to non-glacial stations, although taxa richness was higher in the latter group.

\subsection{Abundance, biomass, and body mass of stream invertebrates}

Invertebrate abundance, total biomass, and average body mass varied according to stream type (Figure 2D) and microhabitat (Figure 3). These parameters showed an approximately unimodal trend over the IHM gradient (Figure 4A,B,E; Table 2), with abundance and biomass peaking at the glacio-rhithral station $\mathrm{Z7}$ (i.e., below the talus), and average body mass peaking at ZRG and at the lower kryal sites Z4-Z5 (i.e., below the moraine).

Bryophyte mats hosted smaller individuals when compared with the mineral substrate $(U=146, p=0.004$; Figure 3). Mixed models revealed the strong and significant effect of the taxon in driving the difference of body mass between the two microhabitats, whereas the stream type was not an important fixed effect (nonsignificant differences between the full and the null models, Supplementary S3; see also Figure 3) although the most abundant taxa exhibited specific patterns of average body mass depending on the sampling station (Supplementary S4). Abundance $(U=457, p<0.001)$ and biomass $(U=415, p=0.002)$ of invertebrates and those of gatherer-collectors ( $U=431$ for abundance, $U=415$ for biomass, $p \leq 0.002$ ) were significantly higher, and grazers abundance was significantly lower $(U=371, p=0.037)$ in the bryophyte mats than in the mineral substrate.

Abundance and biomass of grazers showed peaks over the IHM gradient, corresponding to the moraine (Z4) and talus (Z7) outflows (Figures 2E-F). Shredders increased in abundance as a function of IHM with a significant quadratic relationship $\left(F=45.0, R^{2}=0.69, p<0.001\right)$. Biomass and abundance of gatherer-collectors (logtransformed) showed an asymptotic behaviour along the IHM gradient, with the plateau corresponding to rock glacial, krenal, and glacio-rhithral stations (Figures 2E-F, 4H). Trophic resources were generally correlated with the feeding group relying on them: FPOM was positively correlated with abundance $(\rho=0.81, p<0.001)$ and biomass $(\rho=0.74, p<0.001)$ of gatherer-collectors, whereas CPOM was positively correlated with abundance $(\rho=0.84, p<0.001)$ and biomass $(\rho=0.59, p<0.001)$ of shredders. Chl- $a$ concentrations were positively correlated with the abundance $(\rho=0.44, p<0.001)$ and biomass $(\rho=0.48, p<0.001)$ of grazers, whereas we found no clear relationship between the abundance and biomass of filter-feeders (occurring at high densities 
only at station Z12) and the concentration of suspended solids. The abundance and biomass of predators were positively related to those of invertebrates ( $\rho=0.65$ for abundance, $\rho=0.81$ for biomass; $p<0.001$ ).

\section{DISCUSSION}

Under prolonged glacier retreat, rock glaciers and paraglacial features increasingly influence the alpine river networks (Haeberli, Schaub \& Huggel, 2016; Brighenti et al., 2019b). As the glacial influence declines, nonglacial drivers mediate increasingly milder habitat conditions. These drivers act and interact at different spatial scales, from the landscape (e.g., rock glaciers, moraines, taluses disrupting the environmental gradients along the river continuum) to the microhabitat (e.g., expansion of bryophytes enhancing the retention of organic matter), and promote the amelioration of the habitat. Our Index of Habitat Mildness provides a conceptual framework for describing the patterns of stream invertebrates in the studied area. Organic matter was included in the index due to its key role as a food resource for alpine stream invertebrates (Niedrist \& Füreder, 2017). This parameter was hitherto neglected when building glacial indices, as its abundance only partially depends on the glacier influence.

\subsection{Biotic habitat settings and their ecological implications}

Epilithic biofilm is an important driver of stream biogeochemical cycling and food webs (Niedrist \& Füreder, 2018). Although in our study sites the widespread presence of Hydrurus foetidus may have masked potential differences among stream types in epilithic production, biofilm organic content and Chl-a concentrations were always higher in the lower kryal stations, and in particular the moraine outflow, than the other stream types. The increased abundance and biomass of grazers at the moraine outflow testifies to the contribution of the proglacial lake and the moraine in creating a favourable habitat for primary producers (including bryophytes, that were unexpectedly abundant) and invertebrates.

As expected, the availability of organic detritus increased when moving downstream from the glacier snout due to the enhanced retention capacity of more stable channels and the increasing allochthonous inputs from vegetation, as previously reported (Zah \& Uehlinger, 2001). Our results suggest that the microhabitat had a strong influence on the retention of organic detritus, and shaped the invertebrate metrics. In fact, bryophyte mats trapped on average four times more BOM, and hosted higher abundance and biomass (2.6 and 2.3 times, respectively) of invertebrates than the mineral substrates. Thus, our hypothesis ( $\mathrm{H} 1)$ that bryophytes have higher BOM and invertebrate abundance and biomass, is fully supported by our results. This is in line with a previous study of alpine streams in New Zealand (Suren, 1991), which however only considered invertebrate abundance in the analysis. Our study also showed how bryophytes hosted smaller invertebrates than the mineral substrates. The ratio of first instars among insect larvae was three times higher (six times for Trichoptera, three times for Plecoptera, 2.5 times for Ephemeroptera and Chironomidae) in bryophytes compared to mineral substrates (data not shown), and this confirms the role of bryophyte mats as a nursery microhabitat (SBG, 1999), even in alpine streams.

\subsection{Quantitative patterns of invertebrates along the mildness gradient}


Abundance and biomass of invertebrates showed consistent patterns across stream types and microhabitats, although biomass estimates were much more homogeneous between and within stations than the abundance values. As expected, abundance tended to inflate the importance of smaller taxa and downweigh that of the larger taxa, when compared to biomass. For example, Chironomidae accounted for $74-96 \%$ of the total abundance but only for 13-62 \% of the total biomass of macroinvertebrates at the Solda rock glacial station, where Limnephilidae represented $2-11 \%$ of the abundance but $21-77 \%$ of the biomass. Since the biomass of a population is mediated by the body size of its individuals (e.g., Brown, Gillooly, Allen, Savage \& West, 2004; Hauer \& Lamberti, 2007), this metric might represent a more valuable estimator of the energy use (Pagel, Harvey \& Godfray, 1991), ecological performance (Brown, Allen \& Gillooly, 2007), nutrient cycling (Hall, Koch, Marshall, Taylor, \& Tronstad, 2007), and interactions within food webs (Cohen \& Carpenter, 2007), when compared with the invertebrate density.

The patterns of abundance and biomass, peaking at intermediate mildness, agree with those of previous studies conducted in the Austrian Alps (Füreder, 2007) and the Pyrenees (Khamis, Brown, Hannah \& Milner, 2016). There, the observed peaks of abundance at intermediate levels of meltwater contribution (i.e., 40-60\%; Khamis et al., 2016) or glacier cover in the catchment (i.e., GCC: 15-30\%; Füreder, 2007) were attributed to the low competition/predation typical of intermediate disturbance conditions (i.e., habitat harshness). The GCC (13.7\%) and meltwater contribution (57.8 $\pm 9.7 \%)$ at the talus outflow at Zay were in the same range of those recorded by previous studies (Brighenti et al., 2019b). In contrast, the peaks in abundance that we detected were very high when compared with other points along the gradient, leading to a much more "spiky" trend than those observed by Füreder (2007) and Khamis et al. (2016). Therefore, we suggest that the talus itself, in combination with the mildness gradient, had an important role in boosting the values of abundance and biomass of the Zay stream. In fact, the talus outflow has lower daily and seasonal fluctuations of discharge and water temperature in comparison to downstream and upstream stations (Brighenti et al., 2019b).

Values of biomass and abundance were lower at the Solda rock glacial stream than at the talus outflow, despite comparable habitat mildness. This suggests that the very cold conditions and/or the high concentrations of trace elements (As, U, Sr, Ba) in the rock glacial water (Brighenti et al., 2019b) hinder the invertebrate production, and that the overall habitat mildness is unable to counterbalance this negative effect.

The peaks of average body mass, recorded over the mildness gradient at the Zay rock glacial and the adjacent lower kryal stations, can be mostly attributed to the large size of the caddisfly $A$. zerberus and of the chironomid Pseudodiamesa, that were both abundant in these stations. The lentic character of the Zay rock glacial water likely created a favourable environment for invertebrates. In fact, slow and smooth waters enable an efficient allocation of energy to body growth and allow the survival of larger taxa (Füreder, 1999). In the Zay Stream, the abundance of the large sized taxa upstream and downstream of the rock glacial tributary testifies that the habitat in these lower kryal stations was sufficiently benign to allow their survival, thanks to the buffering effect exerted by the lake/moraine over the glacier influence (Brighenti et al., 2019b). In fact, the moraine outflow had stable channels, extensive bryophyte mats, and a high epilithic production that sustained the invertebrate abundance/biomass. At this station, the biomass of shredders and grazers was among the highest recorded for the entire catchment. Because of the seepage of the lake's outlet into the moraine debris, 
it was impossible to isolate the effects of each of these two paraglacial features on the invertebrate production. However, the role of kryal lakes in increasing macroinvertebrate richness and density was negligible or low in previous studies conducted in the Swiss Alps (Burgherr \& Ward, 2000; Hieber et al., 2005; Sertić Perić \& Robinson, 2015) and Patagonia (Miserendino et al., 2018; Martyniuk, Modenutti \& Balseiro, 2019). This supports our conclusion that the influence of the Zay lake on the benthic invertebrate communities was lower than that of the moraine.

Thus, our second hypothesis $(\mathrm{H} 2)$ that rock glaciers and paraglacial features enhance the diversity and production of invertebrates along the river network is only partially supported by our study. In fact, none of these landforms had a clear influence on the diversity metrics along the glacier-fed stream, but each feature had a distinct but substantial effect on the other metrics: the talus, and secondarily the lake/moraine, boosted the invertebrate abundance and biomass, and the Zay rock glacier and the moraine enhanced the average body mass.

\subsection{Invertebrate communities of a deglaciating catchment}

The positive relationship between the Index of Habitat Mildness, and the total beta diversity and its turnover component, fully supports our hypothesis $(\mathrm{H} 3)$ that the amelioration of the habitat conditions is a key driver for the spatial arrangement of biodiversity, partially driven by distinct water sources. Gradients in glacial influence and groundwater contribution influence the biodiversity patterns (Khamis et al., 2016) and shape the invertebrate community composition of alpine headwaters (e.g., Lencioni, 2018; Füreder \& Niedrist, 2020). Although the relatively low taxonomical precision of our study (namely for Chironomidae, that include a large number of species representing a high fraction of the alpine stream communities; e.g., Lencioni, 2018), may hide some patterns and only permits conclusions to be drawn regarding a fraction of the overall community, the gradient of habitat mildness did explain the shifts in community composition observed in different stream types. The observed dominance of Diamesa in the kryal represents a common feature of these habitats (e.g., Lencioni, 2018), and its relatively high abundance in rock glacial streams can be attributed to the permanently low water temperatures that characterize this stream type $\left(<1.5^{\circ} \mathrm{C}\right)$ and provide suitable conditions for cold adapted taxa. This outcome agrees with a previous study from Lösch, Tolotti \& Alber (2015) on five streams fed by active rock glaciers in South Tyrol, where EPT and Diptera were present, and Diamesa and other Diamesinae were particularly abundant. In particular, these authors found low densities of typical kryal specialists (according to Rossaro, Montagna \& Lencioni, 2016), i.e., Diamesa latitarsis, D. goetghebueri and D. steinboecki. Unfortunately, we cannot draw any conclusion regarding the presence of such species in our study as we identified Chironomidae at the subfamily/genera level. In addition, despite the abundance of Diamesa in the studied rock glacial streams, our results only partially support our hypothesis $(\mathrm{H} 4)$ that the rock glacier invertebrate communities are similar to non-glacial ones. In fact, the Zay rock glacial stream hosted neither Ephemeroptera nor Plecoptera species. The presence of rheophile taxa (e.g., B. alpinus, D. fontium) at the station (which is strongly influenced by the Zay rock glacier; Brighenti et al., 2019b) immediately below the junction with the rock glacial one suggests that their absence in the Zay rock glacial stream is due to its lentic 
conditions. In fact, in line with Lösch et al. (2015), the Solda rock glacial stream (which had a clear lotic character) hosted abundant EPT species that are common dwellers in non-glacial stations.

The abundance of rock glaciers in deglaciating catchments may have two biogeographical implications for alpine stream ecology. First, as rock glacial streams represent mild outposts in the harsh glacier-fed river networks, they may accelerate the spreading of non-glacial communities associated with glacier retreat, thus acting as "stepping stones". In fact, from rock glacial streams, invertebrate taxa that are usually found at much lower elevations (hundreds of meters) can colonise new reaches via drift, successful reproduction of dispersed insects, and/or horizontal movements across the hyporheic zone (see Brighenti et al., 2019a). Krenal habitats located at higher elevations can also act as stepping stones, but they are much less common than those fed by rock glaciers and other permafrost-related landforms (that act as high-mountain aquifers; Hayashi, 2020), and were not present in our study area.

The second biogeographical effect of rock glaciers in deglaciating areas derives from the slower thawing rate of their ice compared to that of glaciers (Haeberli et al., 2016). For this reason, rock glacial streams may represent a longer-lasting habitat compared to the disappearing glacier-fed streams, and may provide cold waters even after complete glacier vanishing (Brighenti et al., 2019a). These "cold water islands" may represent climate refugia (according to Keppel et al., 2012) not only for kryal specialists (Diamesa gr. latitarsis), but also for other species that are considered as "losers" based on their sensitivity to climate change and warming temperatures (e.g., Besacier-Montbertrand et al., 2019; Niedrist \& Füreder, 2020), and that include rare, threatened and/or endemic taxa (e.g., Drusus adustus, endemic of the Eastern Alps, according to Waringer \& Graf, 2011). Rock glacial streams may therefore partially buffer the beta diversity loss predicted in deglaciating alpine areas in the long term (e.g., Fell, Carrivick \& Brown, 2017), as recently proposed for microbes (Hotaling et al., 2019, Tolotti et al., 2020) and for macroinvertebrates in North America (Tronstad et al., 2020).

\section{CONCLUSIONS}

During the advanced stages of glacier retreat, the capacity of rock glaciers and paraglacial features to shape the ecology of alpine streams increases, especially when combined with adjustments at the microhabitat scale such as the expansion of aquatic bryophytes. In deglaciating catchments, ecological shifts are linked to the receding position of glaciers but also to the locations of the extant moraines, rock glaciers, and taluses along the river network, that remain (relatively) constant as deglaciation proceeds. This makes studies of ecological gradients that rely on space-for-time substitutions highly complex and site-specific. For example, new landforms can establish in the freshly exposed glacier forefields (Heckman \& Morche, 2019), and lead to unpredictable ecological shifts in alpine river networks. Our work suggests that the hydrological connection with moraines enhances the production of invertebrates, and particularly those of grazers and shredders, in kryal reaches. Taluses can enhance invertebrate production along the gradients of habitat amelioration due to their hydrological buffering. Rock glacial streams contribute to the riverscape diversity, also by influencing the lentic/lotic conditions that shape the patterns of invertebrate body mass along the river continuum. Streams fed by active rock glaciers are emerging as biodiversity hotspots promoting invertebrate diversity and 
productivity in alpine settings. Because of their different biogeographical roles at different stages of deglaciation, we suggest their function as both "stepping stones" promoting the upstream colonisation by non-glacial communities following glacier retreat, and as "climate refugia" for cold adapted taxa and/or kryal specialists when glaciers disappear. As human pressures increase in the European Alps, the conservation and restoration of rock glacial habitats will be increasingly important in glacier-free landscapes.

\section{DATA AVAILABILITY STATEMENT}

The data that support the findings of this study are provided as Supplementary material. These documents, and the raw table of taxa abundances at different stations and microhabitats, are available from the corresponding author upon reasonable request.

\section{ACKNOWLEDGMENTS}

This research was carried out within the Erasmus Mundus Doctorate Program SMART (http://www.riverscience.eu) funded by the Education, Audiovisual and Culture Executive Agency (EACEA) of the European Commission. The authors thank Michael Engel, Thomas Holtz, Federica Bressan, Federica Rotta, Domiziana Cristini, Giovanni Stefano Andrissi, Olivia West for their precious help during the field activities, and Thomas Holtz and Federica Bressan as well for their valuable work in the laboratory. We are extremely grateful to the anonymous referees and the editor for their comments that helped us to greatly improve this manuscript.

\section{CONFLICT OF INTEREST}

The authors declare no conflict of interest. 


\section{REFERENCES}

Anderson, M. J., Crist, T. O., Chase, J. M., Vellend, M., Inouye, B. D., Freestone, A. L., ... Swenson, N. G. (2011). Navigating the multiple meanings of $\beta$ diversity: a roadmap for the practicing ecologists. Ecology Letters, 14, 19-28. DOI: 10.1111/j.1461-0248-2010.01552.x

Autonomous Province of Bolzano/Bozen - APB (2018). Online Geobrowser v.3. Available online at http://gis2.provinz.bz.it/geobrowser/?project=geobrowser_pro\&view=geobrowser_pro_atlasb\&locale=it

Baselga, A., Orme, D., Villeger, S., DeBortoli, J., \& Leprieur, F. (2017). Betapart: Partitioning beta diversity into turnover and nestedness components. R package version 1.4-1.

Bates, D. M., Maechler, M., \& Bolker, B. (2012). Lme4: Linear mixed-effects models using S4 classes. R package version 0.999999-0

Belfiore, C. 1983. Efemerotteri (Ephemeroptera). In: Ruffo S. (ed.) “Guide per il riconoscimento delle specie animali delle acque interne italiane" C.N.R. AQ/1/201, N.24, 113 pp.

Benke, A. C., Huryn, A. D., Smock, L. A., \& Wallace, J. B. (1999). Length-Mass Relationships for Freshwater Macroinvertebrates in North America with Particular Reference to the Southeastern United States. Journal of the North American Benthological Society, 18(3), 308-343. DOI: 10.2307/1468447

Besacier Monbertrand, A.-L. Timoner, P., Rahman, K., Burlando, P., Fatichi, S., Gonseth, Y. ... Lehman, A. (2019). Assessing the vulnerability of aquatic macroinvertebrates to climate warming in a mountainous watershed: supplementing presence-only data with species traits. Water, 11(636). DOI: $10.3390 /$ w11040636

Breitenmoser-Würsten, C., \& Sartori, M. (1995). Distribution, diversity, life cycle and growth of a mayfly community in a prealpine stream system (Insecta, Ephemeroptera). Hydrobiologia, 308(2), 85-101. DOI: $10.1007 / B F 00007393$

Brighenti, S., Tolotti, M., Bruno, M. C., Wharton, G., Pusch, M. T., \& Bertoldi, W. (2019a). Ecosystem shifts in Alpine streams under glacier retreat and rock glacier thaw: a review. Science of the Total Environment, 675, 542-559. DOI: 10.1016/j.scitotenv.2019.04.221

Brighenti, S., Tolotti, M., Bruno, M. C., Engel, M., Wharton, G., Cerasino, L., Mair, V., \& Bertoldi, W. (2019b). After the peak water: the increasing influence of rock glaciers on alpine river systems. Hydrological Processes, 33(21), 1-20. DOI: 10.1002/hyp.13533

Brown, J. H., Gillooly, J. F., Allen, A. P., Savage, V. M., \& West, G. B. (2004). Toward a metabolic theory of ecology. Ecology, 85(7), 1771-1789. DOI: 10.1890/03-9000

Brown, J. H., Allen, A. P., \& Gillooly, J. F. (2007). The metabolic theory of ecology and the role of body size in marine and freshwater ecosystems. In Hildrew, A. G., Raffaelli, D., \& Edmonds-Brown, R. (Eds.): Body size: the structure and function of aquatic ecosystems. British Ecological Society. Cambridge University Press (New York, USA). 334 pp.

Brown, L. E., Khamis, K., Wilkes, M., Blaen, P., Brittain, J. E., Carrivick, J. L., ... Milner, A. M. (2018). Functional diversity and community assembly of river invertebrates show globally consistent responses to decreasing glacier cover. Nature Ecology \& Evolution, 2, 325-333. DOI: 10.1038/s41559-017-0426-x 
Burgherr, P., \& Ward, J. V. (2000). Zoobenthos of kryal and lake outlet biotopes in a glacial flood plain. SIL Proceedings 1922-2010, 27(3), 1587-1590. DOI: 10.1080/03680770.1998.11901506

Campaioli, S., Ghetti, P. F., Minelli, A., \& Ruffo, S. (1994). Manuale per il riconoscimento dei macroinvertebrati delle acque dolci italiane, Vol. I. Provincia Autonoma di Trento, Italy.

Campaioli, S., Ghetti, P. F., Minelli, A., \& Ruffo, S. (1999). Manuale per il riconoscimento dei macroinvertebrati delle acque dolci italiane, Vol. II. Provincia Autonoma di Trento, Italy.

Clarke, K. R. (1993) Non-parametric multivariate analyses of changes in community structure. Austral Ecology, 18(1), 117-143. DOI: 10.1111/j.1442-9993.1993.tb00438.x

Cohen, J. E. C., \& Carpenter, S. R. (2003). Ecological community description using the food web, species abundance, and body size. Proceedings of the National Academy of Sciences, 100(4), 1781-1786. DOI:10.1073/pnas.232715699

Colombo, N., Salerno, F., Gruber, S., Freppaz, M., Williams, M., Fratianni, S., \& Giardino, M. (2018). Review: Impacts of permafrost degradation on inorganic chemistry of surface fresh water. Global and Planetary Change, 162, 69-83. DOI: 10.1016/j.gloplacha.2017.11.017

Consiglio, C. 1980. Plecotteri (Plecoptera). In: Ruffo S. (ed.) “Guide per il riconoscimento delle specie animali delle acque interne italiane" C.N.R. AQ/1/77, N.9, 68 pp.

Engel M., Penna D., Bertoldi G., Vignoli G., Tirler W., \& Comiti F. (2019). Controls on spatial and temporal variability in streamflow and hydrochemistry in a glacierized catchment. Hydrology and Earth System Sciences, 23, 2041-2063. DOI: 10.5194/hess-23-2041-2019

Fell, S. C., Carrivick, J. L., \& Brown, L. E. (2017). The multitrophic effects of climate change and glacier retreat in mountain rivers. Bioscience, 67(10), 897-911. DOI: 10.1093/biosci/bix107

Finn, D., Rasanen K., \& Robinson, C.T. (2010). Physical and biological changes to a lengthening stream gradient following a decade of rapid glacial recession. Global Change Biology, 16(12), 3314-3326. DOI: 10.1111/j.1365-2486.2009.02160.x

Füreder, L. (1999). High alpine streams: cold habitats for insect larvae. In Cold-adapted organisms: ecology, physiology, enzymology and molecular biology (pp. 181-196). Berlin, Heidelberg, Germany: Springer Berlin Heidelberg

Füreder, L. (2007). Life at the edge: Habitat condition and bottom fauna of alpine running waters. International Review of Hydrobiology, 92(4-5), 491-513. DOI: 10.1002/iroh.200610987

Füreder, L., \& Niedrist, G. H. (2020). Glacial stream ecology: structural and functional assets. Water, $12,376$. DOI: $10.3390 / w 12020376$

Giustini, M., Miccoli, F. P., De Luca, G., \& Cicolani, B. (2008). Lemght-weight relationships for some plecoptera and ephemeroptera from a carbonate stream in central Appennine (Italy). Hydrobiologia, 605, 183191. DOI: $10.1007 / s 10750-008-9353-9$

Haeberli, W., Schaub, Y., \& Huggel, C. (2016). Increasing risks related to landslides from degrading permafrost into new lakes in de-glaciating mountain ranges. Geomorphology, 293, 405-417. DOI: 10.1016/j.geomorph.2016.02.009

Hall, R. O., Koch, B. J., Marshall, M. C, Taylor, B. W., \& Tronstad, L. M. (2007). How body size mediates the role 
of animals in nutrient cycling in aquatic ecosystems. In Hildrew, A. G., Raffaelli, D., \& Edmonds-Brown, R. (Eds.): Body size: the structure and function of aquatic ecosystems. British Ecological Society. Cambridge University Press (New York, USA). 334 pp.

Hauer, F. R., \& Lamberti, G. A. (1996). Methods in stream ecology. Academic Press, San Diego, CA, pp. $579-589$ Hayashi, M. (2020). Alpine Hydrogeology: The Critical Role of Groundwater in Sourcing the Headwaters of the World. Groundwater, 58, 498-510. DOI: 10.1111/gwat.12965

Heckman, T., \& Morche, D. (2019). Gemorphology of Proglacial Systems. Landform and Sediment Dynamics in Recently Deglaciated Alpine Landscapes. Geography of the Physical Environment, Springer Nature Geneve (Switzerland). 352 pp. ISBN 978-3-319-94182-0

Herbst, D. H., Cooper, S. D., Medhurst, R. B., Wiseman, S. W., \& Hunsaker, C. T. (2018). A comparison of the taxonomic and trait structure of macroinvertebrate communities between the riffles and pools of montane headwater streams. Hydrobiologia, 820, 115-133. DOI 10.1007/s10750-018-3646-4

Hieber, M., Robinson, C. T., Uehlinger, U., \& Ward, J. V. (2005). A comparison of benthic macroinvertebrate assemblages among different types of alpine streams. Freshwater Biology, 50(12), 2087-2100. DOI: 10.1111/j.1365-2427.2005.01460.x

Hotaling S., Finn D. S., Giersch J. J., Weisrock D. W., \& Jacobsen D. (2017). Climate change and alpine stream biology: progress, challenges, and opportunities for the future. Biological Reviews, 92, 2024-2045. DOI:10.1111/brv.12319

Hotaling, S., Foley, M. E., Zeglin, L. H., Finn, D. S., Tronstad, L. M., Giersch, J. J., ... Weisrock, D. W. (2019). Microbial assemblages reflect environmental heterogeneity in alpine streams. Global Change Biology, 25, 2576-2590. DOI: 10.1111/gcb.14683

Huss, M., Bookhagen, B., Huggel, C., Jacobsen, D., Bradley, R. S., Clague, J. J., ... Winder, M. (2017). Toward mountains without permanent snow and ice. Earth's Future, 5, 418-435. DOI: 10.1002/ 2016 EF000514

IBM (2018). SPSS Statistics software, v.26

Ilg, C., \& Castella, E. (2006). Patterns of macroinvertebrate traits along three glacial stream continuums. Freshwater Biology, 51(5), 840-853. DOI: 10.1111/j.1365-2427.2006.01533.x

Intergovernmental Panel on Climate Change - IPCC (2019). IPCC Special Report on the Ocean and Cryosphere in a Changing Climate. Genf, Switzerland.

Johnston, T. A., \& Cunjak, R. A. (1999). Dry mass-length relationships for benthic insects: a review with new data from Catamaran Brook, New Brunswick, Canada. Freshwater Biology, 41, 653-674. DOI: 10.1046/j.1365-2427.1999.00400.x

Jones, D. B., Harrison, S., Anderson, K., \& Whalley, W. B. (2019). Rock glaciers and mountain hydrology: A review. Earth-Science Reviews, 193, 66-90. DOI: 10.1016/j.earscirev.2019.04.001

Keppel, G., Van Niel, K. P., Wardell-Johnson, G. W., Yates, C. J., Byrne, M., Mucina, L., Schut, A. G. T., Hopper, S. D. and Franklin, S. E. (2012), Refugia: identifying and understanding safe havens for biodiversity under climate change. Global Ecology and Biogeography, 21: 393-404. doi:10.1111/j.1466-

8238.2011.00686.x 
Khamis, K., Brown, L. E., Hannah, D. M., \& Milner, A. M. (2016). Glacier - groundwater stress gradients control alpine river biodiversity. Ecohydrology. DOI: 10.1002/eco.1724

Krumbein, W. C. (1934). Size frequency distributions of sediments. Journal of Sedimentary Petrology, 2(4), 6577. DOI: 10.1306/D4268EB9-2B26-11D7-8648000102C1865D.

Lencioni, V. (2018). Glacial influence and stream macroinvertebrate biodiversity under climate change: Lessons from the Southern Alps. Science of the Total Environment, 622-623, 563-575. DOI: 10.1016/j.scitotenv.2017.11.266

Lencioni, V., Marziali, L., \& Rossaro, B. (2007). I Ditteri Chironomidi: morfologia, tassonomia, ecologia, fisiologia e zoogeografia. Quaderni del Museo Tridentino di Scienze Naturali. Trento. 171 pp.

Lösch, B., Tolotti, M., \& Alber, R., (2015). Permafrost und Gewässerökologie - Quellen und Bäche mit Blockgletschereinfluss. Geo.Alp, 12, 163-182

Martyniuk, N., Modenutti, B., \& Balseiro, E. G. (2019). Seasonal variability in glacial influence affects macroinvertebrate assemblages in North-Andean Patagonian glacier-fed streams. Inland Waters, 112. DOI: $10.1080 / 20442041.2019 .1624115$

Merritt, R. W., Resh, V. H., \& Cummins, K. W. (1996). Design of aquatic insect studies: collecting sampling, and rearing procedures. In: An introduction to the aquatic insects of North America. R. W. Merritt and K. W. Cummins eds. $3^{\text {rd }}$ edition. Kendall/Hunt Publishing Company, Dubunque, lowa.

Méthot, G., Hudon, C., Gagnon, P., Pinel-Alloul, B., Armellin, A., \& Tourville Poirier, A.-M. (2012). Macroinvertebrate size-mass relationships: How specific should they be?, Freshwater Science, 31(3), 750-764. DOI: 10.1899/11-120.1

Milner, A. M., \& Petts, G. E. (1994). Glacial rivers: physical habitat and ecology. Freshwater Biology, 32(2), 295307. DOI: 10.1111/j.1365-2427.1994.tb01127.x

Milner, A. M., Brittain, J., Castella, E., \& Petts, J. E. (2001). Trends of macroinvertebrates community structure in glacier-fed rivers in relation to environmental conditions: a synthesis. Freshwater Biology, 46(12): 1833-1847, DOI: 10.1046/j.1365-2427.2001.00861.x

Milner, A. M., Brown, L. E., \& Hannah, D. M. (2009). Hydroecological response of river systems to shrinking glaciers. Hydrological Processes, 23 (1), 62-77. DOI: 10.1002/hyp.7197

Milner, A. M., Khamis, K., Battin, T. J., Brittain, J. E., Barrand, N. E., Füreder, L., ... Brown, L. (2017). Glacier shrinkage driving global changes in downstream systems. Proceedings of the National Academy of Sciences, 114(37), 9770-9778. DOI: 10.1073/pnas.1619807114

Miserendino, M. L., Brand, C., Epele, L. B., Di Prinzio, C. Y., Omad, G. H., Archangelsky, M., ... Kutschker, A. M. (2018). Biotic diversity of benthic macroinvertebrates at contrasting glacier-fed systems in Patagonia mountains: the role of the environmental heterogeneity facing global warming. Science of the Total Environment, 622-623, 152-153. DOI: 10.1016/j.scitotenv.2017.11.320

Montrasio, A., Berra, F., Cariboni, M., Ceriani., M., Deichmann, N., Longhin, M., ... Zappone, A. (2015). Note illustrative della Carta Geologica d'Italia, Foglio 024-Bormio. ISPRA-SGI-Regione Lombardia

Niedrist, G., H., \& Füreder, L. (2017). Trophic ecology of alpine stream invertebrates: current status and future research needs. Freshwater Science, 36(3), 466-478. DOI:10.1086/692831 
Niedrist, G. H., \& Füreder, L. (2018). When the going gets tough, the tough get going: the enigma of survival strategies in harsh glacial stream environments. Freshwater Biology, 2018; 00:1-13. DOI: $10.1111 /$ fwb.13131

Niedrist, G. H., \& Füreder, L. (2020). Real-time warming of alpine streams: (re)defining invertebrate's temperature preferences. River Research and Applications, 1-11. DOI: 10.1002.rra.3638

Niedrist, G. H., Cantonati, M., \& Füreder, L. (2018). Environmental harshness mediates the quality of periphyton and chironomid body mass in alpine streams. Freshwater Science, 37(3): 519-533. DOI:10.1086/699480

Nolte, U. (1990). Chironomid biomass determination from larval shape. Freshwater Biology, 24, 443-451.

Oksanen, J., Blanchet, F. G., Kindt, R., Legendre, P., Minchin, P. R., O’hara, R. B., ... Wagner, H. (2018). Vegan: community ecology. $R$ package version 2.4-6.

Pagel, M. D., Harvey, P. H., \& Godfray, H. C. J. (1991). Species-abundance, Biomass and resource use distributions. The American Naturalist, 138(4), 836-850. DOI: 2462436

Pfankuch D.J. (1975) Stream Reach Inventory and Channel Stability Evaluation. US Department of Agriculture Forest Service, Region 1, Missoula, Montana, 26 pp.

R Development Core Team (2017). R: a language and environment for statistical computing. R Foundation for Statistical Computing, Vienna, Austria. https://www.R-project.org/

Rossaro, B., Montagna, M., \& Lencioni, V. (2016). Environmental traits affect chironomid communities in glacial areas of the Southern Alps: Evidence from a long-lasting case study. Insect Conservation and Diversity, 9(3), 192-201. DOI: 10.1111/icad.12157

Sertić Perić, M., \& Robinson, C. T. (2015). Spatio-temporal shifts of macroinvertebrate drift and benthos in headwaters of a retreating glacier. Hydrobiologia, 751(1), 25-41. DOI: 10.1007/s10750-014-2149-1

Steinmann, A. D., Lamberti, G. A., \& Leavitt, P. L. (1996). Biomass and pigments of benthic algae. In : Methods in stream ecology (Hauer, \& Lamberti, Eds.). Academic Press, San Diego, CA.

Stream Bryophyte Group - SBG (1999). Roles of Bryophytes in stream ecosystems. Journal of the North American Benthological Society, 18(2), 151-184. DOI:10.2307/1468459

Suren, A. M. (1991). Bryophytes as invertebrate habitat in two New Zealand alpine streams. Freshwater Biology, 26(3), 399-418. DOI: 10.1111/j.1365-2427.1991.tb01407.x

Tolotti, M., Cerasino, L., Donati, C., Pindo, M., Rogora, M., Seppi, R., \& Albanese, D. (2020). Alpine headwaters emerging from glaciers and rock glaciers host different bacterial communities: Ecological implications for the future. Science of the Total Environment, in press. DOI: 10.1016/j.scitotenv.2020.137101

Tronstad, L. M., Hotaling, S., Giersch, J. J., Wilmot, O. J., \& Finn, D. S. (2020). Headwaters fed by subterranean ice: potential climate refugia for mountain stream communities? bioRxiv 788273. DOI: $10.1101 / 788273$

Waringer, J., \& Graf, W. (2011). Atlas of central European Trichoptera larvae. 468 pp. Erick Mauch Verlag, Germany. ISBN: 978-3-00-032177-1

Wood, S.N. (2006). Generalized Additive Models: An Introduction with R. (eds. Carlin, B.P., Chatfield, C., Tanner, M. \& Zidek, J.). Chapman and Hall/CRC, Boca Raton, Florida. 
World Glacier Monitoring Service - WGMS (2018). Fluctuations of glaciers browser. Powered by ESRi Suisse, Zurich, version 2.0. Available at: https://wgms.ch/fogbrowser/

Zah, R., \& Uehlinger, U. (2001). Particulate organic matter inputs to a glacial stream ecosystem in the Swiss Alps. Freshwater Biology, 46(12), 1597-1608. DOI: 10.1046/j.1365-2427.2001.00847.x

Zuur, A. F., leno, E. N., Walker, N., Saveliev, A. A., \& Smith, G. (2009). Mixed effects models and extensions in ecology with R. New York: Springer

Zwick, P., \& Zwick, H. (2010). The life history and development of Dictyogenus fontium (Plecoptera: Perlodidae) in two thermally contrasting streams at Lunz am See, Lower Austria 1. Denisia, 29, 459-475 

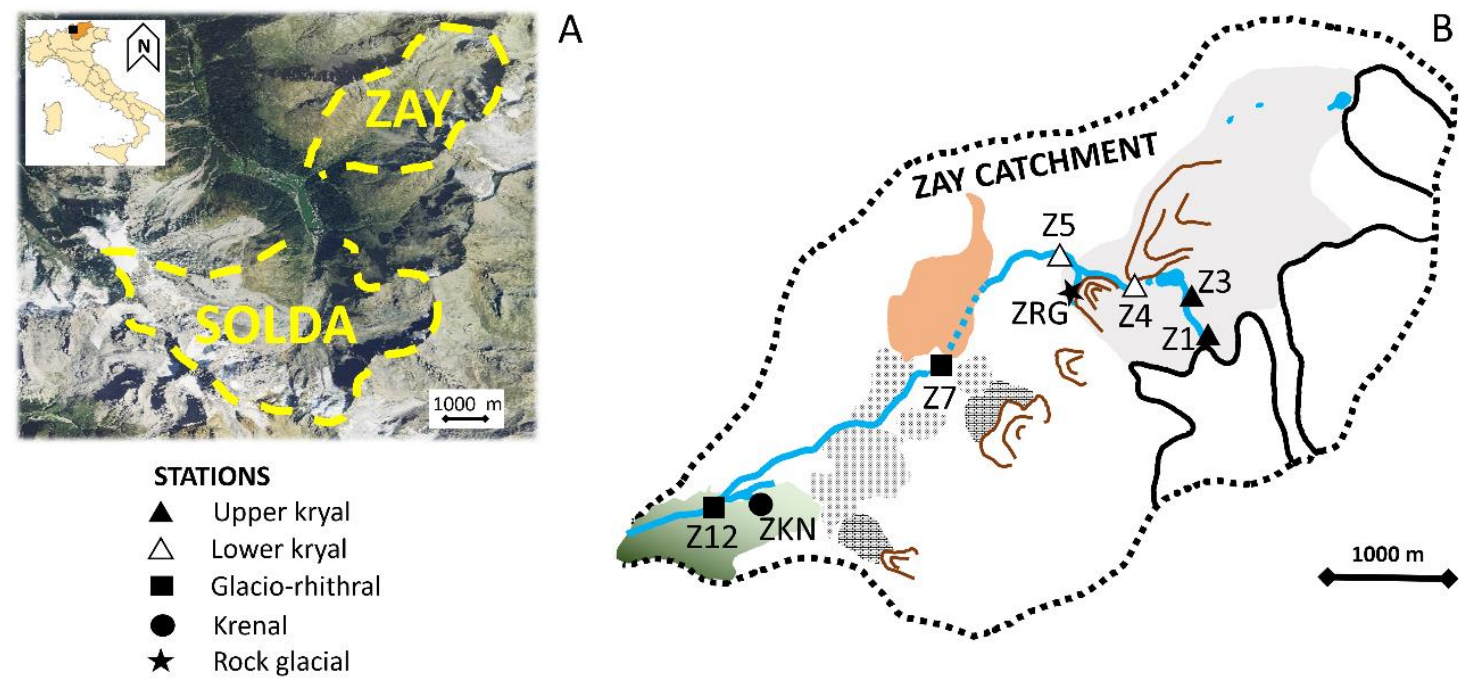

WATER BODIES

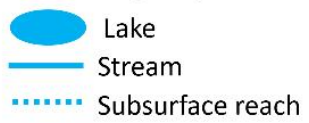

FEATURES

$\bigcirc$ Glacier

2) Active rock glacier

Moraine deposit

Talus slope

Inactive rock glacier

Relict rock glacier

Increasing tree cover

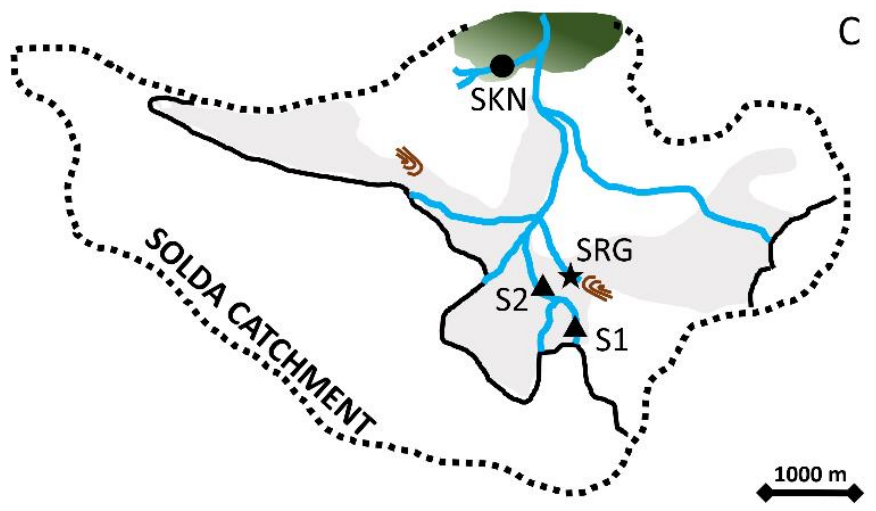

Figure 1. Study area. A) Geographic location of the study area; Schematic hydromorphological setting and locations of the sampling stations for: B) Zay subcatchment; C) Upper Solda subcatchment. 

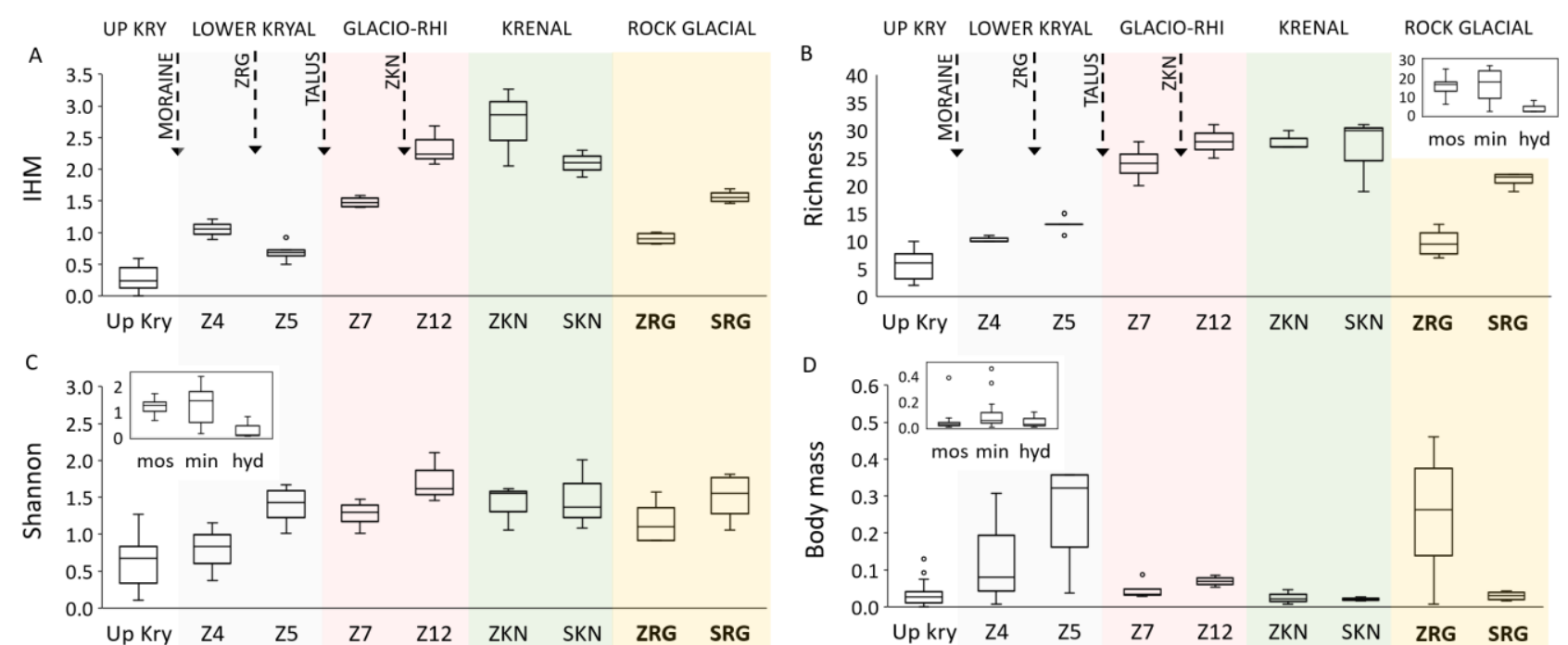

D
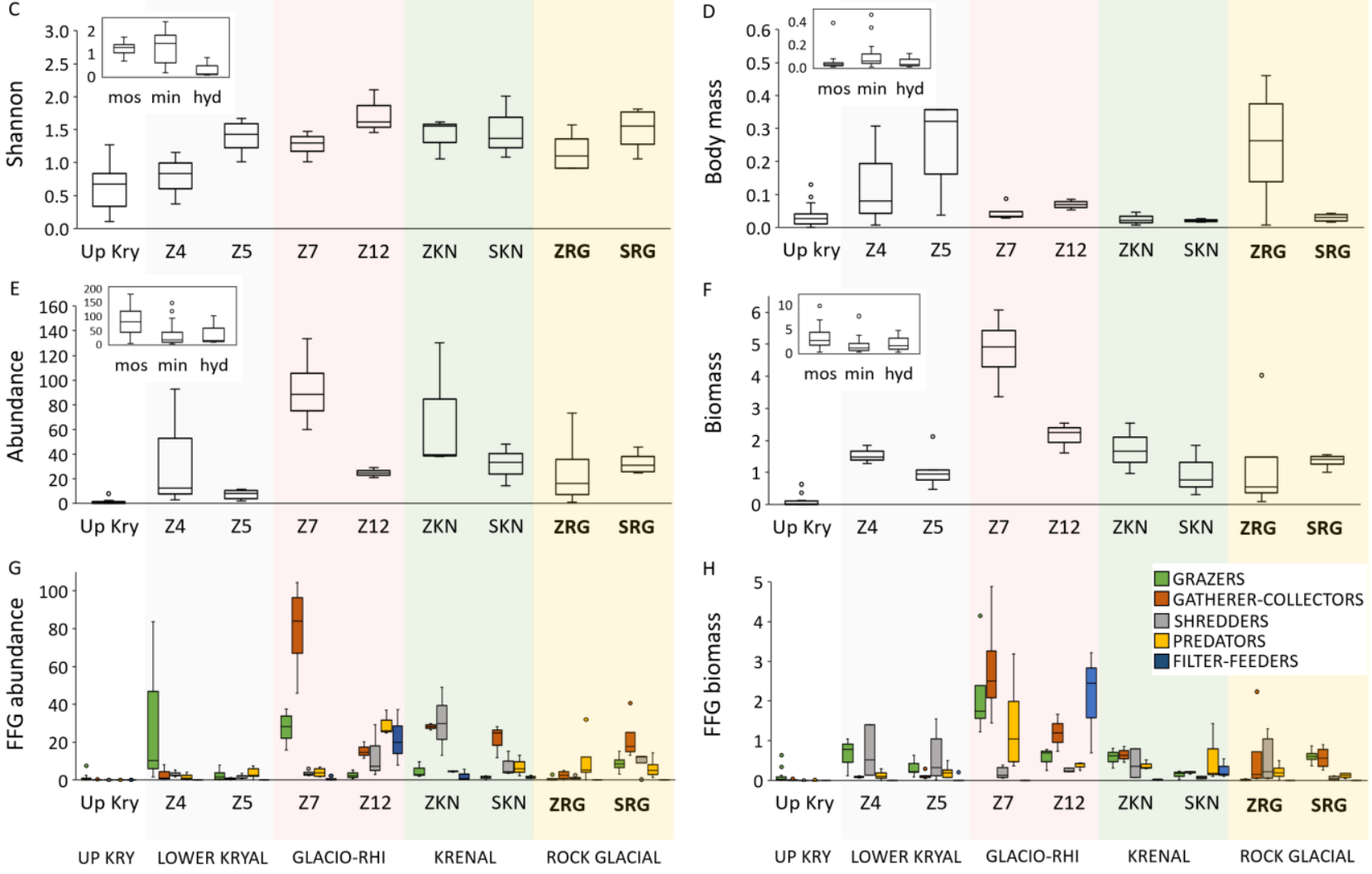

Figure 2. Community metrics at different stations: A) Index of habitat mildness; B) Taxa richness (total number of taxa) and C) Shannon index at different stream types; D-H) Quantitative community metrics associated with the different sampling stations (large boxplots) and microhabitats (small boxplots, $\mathrm{min}=$ mineral, $\mathrm{mos}=$ bryophytes, Hyd= H. foetidus). D) Average invertebrate body mass (mg ind ${ }^{-1}$ dry mass); E) Invertebrate abundance (i.e., density, $10^{3}$ Ind. $\mathrm{m}^{-2}$; F) Invertebrate biomass ( $\mathrm{g} \mathrm{m}^{-2}$, meiofaunal taxa and pupae excluded) G) Functional feeding group abundances; H) Functional feeding group biomasses. The legend for FFGs is displayed in $\mathrm{H}$ ). To allow comparison among FFGs the abundance of filter-feeders and predators was multiplied per 10 and the biomass of filter-feeders per 100. Upper kryal stations (Up Kry) are pooled together due to little variability in the metrics; rock glacial stations, in bold, are kept separated; arrows in the upper part of the figure indicate the position of each tributary/landform along the Zay stream. 

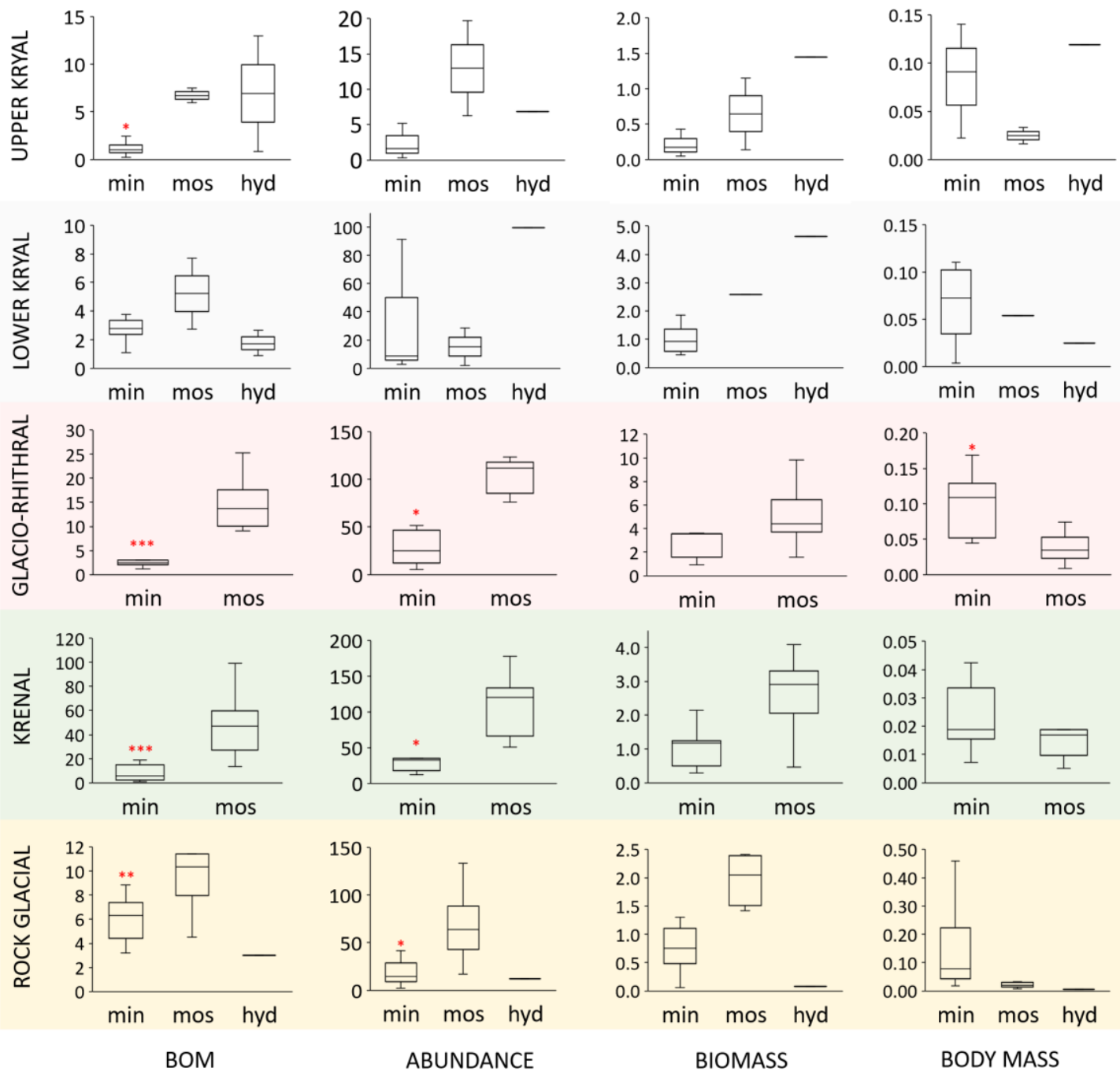

Figure 3. Pairwise boxplots of benthic organic matter (BOM, $\left.\mathrm{g} \mathrm{m}^{-2}\right)$, invertebrate abundance $\left(10^{3} \mathrm{Ind} . \mathrm{m}^{-2}\right)$ and biomass $\left(\mathrm{g} \mathrm{m}^{-2}\right)$, and average invertebrate body mass $\left(\mathrm{mg}\right.$ ind $\left.{ }^{-1}\right)$ in different microhabitats ( $\mathrm{min}=$ mineral substrate, mos= bryophyte mats and Hyd= Hydrurus foetidus patches) for each stream type. Significance values $\left({ }^{*} p<0.05,{ }^{* *} p<0.01,{ }^{* * *} p<0.001\right)$ plotted only in the pairwise comparisons between mineral substrates and bryophytes, given the low numbers of $H$. foetidus samples ( $N=1$ for all boxplots where it is shown). 

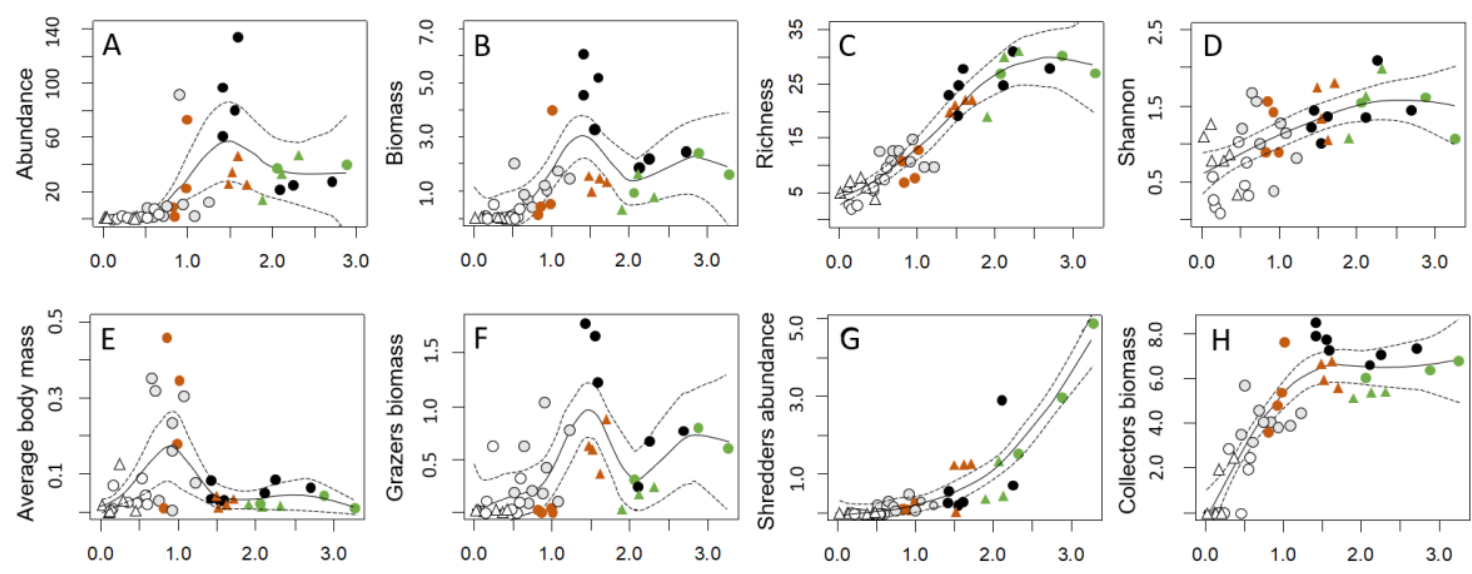

Legend

Catchment

$\Delta$ Solda

- Zay

Stream type $\square$ Upper kryal

$\square$ Lower kryal

- Glacio-rhithral

$\square$ Krenal

$\square$ Rock glacial

Figure 4. Community metrics over the mildness gradient: A) Invertebrate abundance $\left(10^{3}\right.$ ind. $\left.\mathrm{m}^{-2}\right)$; B)

Invertebrate biomass $\left(\mathrm{g} \mathrm{m}^{-2}\right.$ ), C) Taxa richness; D) Shannon index; E) Average body mass (mg ind.$^{-1}$ ). F) grazers biomass; G) shredders abundance $H) \log (x+1)$ transformed gatherer-collectors biomass. See Table 2 for model characteristics. Continuous lines represent the best fit and dashed lines represent $95 \%$ confidence intervals. The slight deflection of the Shannon diversity over the gradient is attributed to the freshly hatched eggs pockets of (overrepresented) Chironomidae at ZKN (June 2017). 


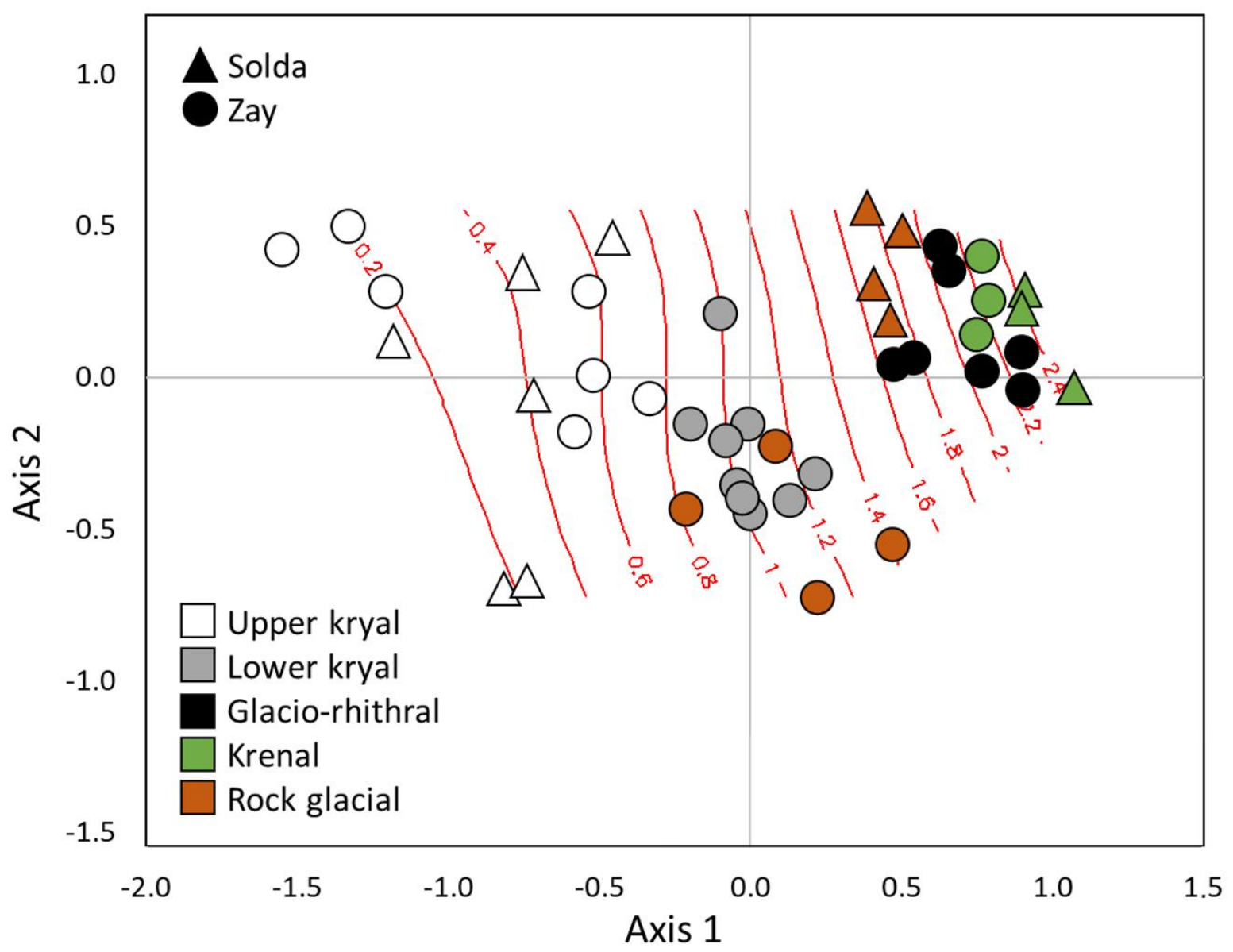

Figure 5. Non-metric multidimensional scaling ordination biplot of sampling stations, according to catchment (geometric shapes) and stream type (colours), for the $\log (x+1)$ transformed dataset of taxa abundances. Red lines specify areas of equal habitat mildness (IHM) in the NMDS space, and were obtained with the ordisurf function of the package vegan (Oksanen et al., 2018). This function fits a smoothed surface in the NMDS space based on generalized additive models. 
Table 1. Main features of the study sites. Discharge $(Q=$ discharge range) was estimated with the salt-dilution method during summer 2018 (June/July and the end of September, respectively). For the remaining variables: mean and standard deviation ( $95 \%$ confidence) for each stream type, interval range at each sampling station. Veg= Riparian vegetation, classes: $0=$ sparse/absent, $1=$ discontinuous alpine heat, $2=$ continuous alpine heat, $3=$ alpine heat with sparse trees and shrubs, $4=$ canopy from trees and shrubs. Mos= abundance of bryophytes in the channel, classes: $0=0-5 \%, 1=5-10 \%, 2=10-30 \%, 3=30-50 \%$. PFAN bot $=$ bottom component of the Pkankuch index, proxy for the instability of the channel (Pfankuch, 1975). T= average water temperature, from 15 June to 25 September 2017 and 2018 . EC=electrical conductivity. ${ }^{\text {a }}$ station added in August 2017. ${ }^{\mathrm{b}}$ Station added in June 2018. ${ }^{\mathrm{c}}$ Refers to 2019 summer only. ${ }^{\mathrm{d}}$ Assessed with width-depth-velocity transects. See Brighenti et al. (2018b) for more details on the sampling stations.

\begin{tabular}{|c|c|c|c|c|c|c|c|c|c|c|c|}
\hline Stations & Veg & Mos & PFAN $_{\text {bot }}$ & $\begin{array}{l}Q \\
\left(I s^{-1}\right)\end{array}$ & $\begin{array}{l}\mathrm{T} \\
\left({ }^{\circ} \mathrm{C}\right)\end{array}$ & $\begin{array}{l}\text { Turbidity } \\
\text { (NTU) }\end{array}$ & $\begin{array}{l}\mathrm{EC} \\
\left(\mu \mathrm{S} \mathrm{cm}^{-1}\right)\end{array}$ & $\mathrm{pH}$ & $\begin{array}{l}\text { Chl-a } \\
\left(\mu \mathrm{cm}^{-2}\right)\end{array}$ & $\begin{array}{l}\text { Epilithic biofilms } \\
\left(\mathrm{g} \mathrm{m}^{-2}\right)\end{array}$ & $\begin{array}{l}\mathrm{BOM} \\
\left(\mathrm{g} \mathrm{m}^{-2}\right)\end{array}$ \\
\hline Upper kryal & & & & & $1.4 \pm 1.1$ & $69 \pm 64$ & $126 \pm 149$ & $7.0 \pm 0.9$ & $0.1 \pm 0.2$ & $1.5 \pm 1.3$ & $1.5 \pm 1.2$ \\
\hline SI & 0 & 0 & 58 & $1-136$ & $0.1-0.5$ & $7-302$ & $9-88$ & $6.9-8.9$ & 0.0 & $0.7-3.8$ & $0.2-4.4$ \\
\hline S2 & 0 & 0 & 59 & $96-458$ & $1.6-2.9$ & $8-141$ & $103-537$ & $6.9-8.0$ & $0.0-0.2$ & $1.0-3.7$ & $0.9-1.9$ \\
\hline $\mathrm{Z1}$ & 0 & 0 & 54 & $5-30$ & $0.2-1.8$ & $15-95$ & $15-270$ & $5.4-7.1$ & $0.0-0.6$ & $0.0-1.1$ & $0.5-4.5$ \\
\hline Z3 & 1 & 0 & 50 & $4-38$ & $0.6-3.2$ & $15-88$ & $15-245$ & $5.3-6.9$ & $0.0-0.6$ & $0.7-4.1$ & $0.7-3.5$ \\
\hline Lower kryal & & & & & $2.6 \pm 0.9$ & $11 \pm 4$ & $93 \pm 42$ & $6.7 \pm 0.2$ & $3.9 \pm 4.3$ & $10.9 \pm 7.6$ & $3.2 \pm 1.8$ \\
\hline Z4a & 1 & 3 & 25 & $149-300$ & $1.7-3.2$ & $8-15$ & $63-106$ & $6.3-6.9$ & $1.6-14.3$ & $5.3-26.0$ & $1.8-4.3$ \\
\hline $\mathrm{Z5}$ & 1 & 1 & 44 & $156-324$ & $1.7-4.5$ & $5-20$ & $60-195$ & $6.4-7.2$ & $0.8-7.8$ & $1.8-14.6$ & $1.2-7.9$ \\
\hline Glacio-rhithral & & & & & $4.8 \pm 1.2$ & $11 \pm 5$ & $85 \pm 26$ & $6.5 \pm 0.5$ & $1.4 \pm 1.1$ & $4.7 \pm 3.0$ & $11.5 \pm 3.5$ \\
\hline $\mathrm{Z7}$ & 2 & 3 & 30 & $240-467$ & $3.4-5.4$ & $6-27$ & $58-122$ & $6.3-7.0$ & $0.5-2.2$ & $1.3-5.1$ & $6.8-11.9$ \\
\hline $\mathrm{Z} 12^{\mathrm{b}}$ & 4 & 2 & 30 & $c 170-550$ & $4.2-7.3$ & $5-12$ & $74-123$ & $5.3-6.8$ & $0.7-3.6$ & $3.6-11.0$ & $13.7-17.4$ \\
\hline Krenal & & & & & $4.0 \pm 1.1$ & $4 \pm 7$ & $174 \pm 44$ & $7.1 \pm 0.5$ & $0.7 \pm 0.6$ & $3.3 \pm 1.1$ & $23.3 \pm 11.5$ \\
\hline ZKN & 4 & 3 & 18 & $8-10$ & $2.7-3.5$ & $0-2$ & $121-142$ & $6.4-7.1$ & $0.3-2.1$ & $2.9-4.9$ & $14.5-43.2$ \\
\hline SKN & 3 & 2 & 37 & $29-32$ & $4.1-6.0$ & $0-9$ & $185-238$ & $7.3-7.8$ & $0.1-0.7$ & $2.0-3.3$ & $6.7-35.2$ \\
\hline Rock glacial & & & & & $1.1 \pm 0.1$ & $6 \pm 6$ & $314 \pm 215$ & $7.1 \pm 0.5$ & $1.2 \pm 0.7$ & $5.7 \pm 4.3$ & $8.1 \pm 2.5$ \\
\hline ZRG & 2 & 1 & 30 & ${ }^{c-d} 28-173$ & $0.9-1.3$ & $4-22$ & $66-250$ & $6.4-7.1$ & $0.8-2.6$ & $3.7-15.9$ & $3.2-11.3$ \\
\hline SRG & 2 & 3 & 18 & $29-46$ & $0.9-1.3$ & $2-3$ & $376-630$ & $7.3-7.6$ & $0.5-2.3$ & $1.3-6.3$ & $6.5-11.2$ \\
\hline
\end{tabular}


Table 2. Results from the GAM analyses. For each analysis the dependent variable, the smoothing function, $\mathrm{F}$ $/ \chi^{2}$ values, $p$-value and the deviance associated with the mildness gradient (IHM as explanatory variable) are listed. To ensure homoscedasticity of residuals outliers (Z5 September 2017 for average body mass Z4 June 2018 and $Z 7$ June 2017 for grazers abundance) were removed or $\left({ }^{\log }\right)$ a $\log (x+1)$ transformation was applied. For invertebrate abundance, ZKN June 2017 was removed from the analysis because $60 \%$ of the sample abundance was composed of first instars of Chironomidae coming from freshly hatched egg pockets.

\begin{tabular}{|c|c|c|c|c|}
\hline Dependent & Family & $\mathrm{F} / \mathrm{X}^{2}$ & $p$ & Deviance \\
\hline Invertebrate abundance & Negative binomial & 193.9 & $<0.01$ & $73.2 \%$ \\
\hline Invertebrate biomass & Gaussian & 5.49 & $<0.001$ & $53.3 \%$ \\
\hline Average body mass & Gamma(Link=log) & 5.17 & $<0.001$ & $40.1 \%$ \\
\hline Richness & Negative binomial & 187.9 & $<0.001$ & $87.5 \%$ \\
\hline Shannon diversity & Gaussian & 9.87 & $<0.001$ & $42.7 \%$ \\
\hline Shredders abundance & Gaussian & 18.35 & $<0.001$ & $83.1 \%$ \\
\hline Grazers abundance & Negative binomial & 37.34 & $<0.001$ & $36.9 \%$ \\
\hline Grazers biomass & Gaussian & 3.97 & $<0.001$ & $50.9 \%$ \\
\hline Collectors abundance ${ }^{\log }$ & Gaussian & 48.52 & $<0.001$ & $88.2 \%$ \\
\hline Collectors biomass ${ }^{\log }$ & Gaussian & 39.95 & $<0.001$ & $88.2 \%$ \\
\hline
\end{tabular}

Table 3. Correlation between NMDS axes scores and taxa $(\log (x+1)$-transformed) abundances. Only taxa with $|R|>0.5$ are listed

\begin{tabular}{lll}
\hline Taxon & NMDS1 & NMDS2 \\
\hline Orthocladiinae & 0.88 & 0.15 \\
Enchytraeidae & 0.82 & -0.14 \\
Baetis alpinus & 0.78 & 0.40 \\
Nemoura mortoni & 0.73 & 0.53 \\
Tanytarsini & 0.72 & 0.30 \\
Dictyogenus fontium & 0.69 & 0.42 \\
Protonemura nitida & 0.69 & 0.28 \\
Hydrachnidia & 0.66 & 0.31 \\
Leuctra rosinae & 0.64 & 0.38 \\
Simuliidae & 0.60 & 0.23 \\
Copepoda & 0.60 & -0.20 \\
Protonemura brevistyla & 0.57 & 0.33 \\
Nematoda & 0.57 & -0.40 \\
Limoniidae & 0.56 & 0.38 \\
Isoperla rivulorum & 0.54 & 0.29 \\
Rhithrogena loyolaea & 0.54 & 0.12 \\
Drusus cf. adustus & 0.53 & 0.41 \\
Pediciidae & 0.51 & 0.12 \\
Pseudodiamesa & 0.11 & -0.54 \\
\hline
\end{tabular}


SUPPLEMENTARY MATERIAL

Supplementary S1. Protocol for the assessment of BOM storage in the mineral substrate.

Supplementary S2. Conversion factors for size-mass equations.

Supplementary S3. Linear mixed-effects models performed and results.

Supplementary S4. Boxplots of the average body mass ( $\mathrm{mg} \mathrm{ind}^{-1}$ of dry mass) of the most abundant taxa in each sampling station. 
Supplementary S1. List of taxa abundances (ind. $\mathrm{m}^{-2}$ ) for each station. Microhabitat for each station, and number of replicates for each microhabitat are provided in the heading. Microhabitat: min= inorganic substrate; mos= bryophyte mats; mix= microhabitat replicates $(\mathrm{min}, \mathrm{mos})$ pooled in the same sample; san= sand/silt; bou= boulders; Hyd= Hydrurus foetidus. Stations typology: Upper kryal: S1, S2, Z1, Z3; Lower kryal: Z4, Z5; krenal: ZKN, SKN; glacio-rhithral: Z7, Z12; rock-glacier-fed: SRG, ZRG. 


\begin{tabular}{|c|c|c|c|c|c|c|c|c|c|c|c|c|c|c|}
\hline $\begin{array}{l}\text { microhabitat } \\
\mathrm{n}^{\circ} \text { replicates }\end{array}$ & $\begin{array}{c}\text { S1 } \\
\min \\
5\end{array}$ & $\begin{array}{c}\text { S2 } \\
\min \\
5\end{array}$ & $\begin{array}{c}\text { Z3 } \\
\operatorname{mix} \\
5\end{array}$ & $\begin{array}{c}\mathbf{Z 5} \\
\min \\
5\end{array}$ & $\begin{array}{c}\mathbf{Z 7} \\
\min \\
4\end{array}$ & $\begin{array}{c}\mathbf{Z 7} \\
\text { mos } \\
1\end{array}$ & $\begin{array}{c}\text { ZKN } \\
\min \\
3\end{array}$ & $\begin{array}{c}\text { ZKN } \\
\text { mos } \\
2\end{array}$ & $\begin{array}{c}\text { SKN } \\
\operatorname{mix} \\
5\end{array}$ & $\begin{array}{c}\text { ZRG } \\
\text { san } \\
2\end{array}$ & $\begin{array}{c}\text { ZRG } \\
\text { bou } \\
2\end{array}$ & $\begin{array}{c}\text { ZRG } \\
\text { mos } \\
1\end{array}$ & $\begin{array}{c}\text { SRG } \\
\min \\
3\end{array}$ & $\begin{array}{c}\text { SRG } \\
\text { mos } \\
2\end{array}$ \\
\hline \multicolumn{15}{|l|}{ TURBELLARIA } \\
\hline Crenobia alpina (Dana, 1766) & 0 & 0 & 0 & 0 & 0 & 0 & 0 & 0 & 32 & 0 & 0 & 0 & 0 & 0 \\
\hline NEMATODA & 4 & 0 & 68 & 1056 & 0 & 0 & 0 & 0 & 1328 & 240 & 0 & 120 & 0 & 0 \\
\hline \multicolumn{15}{|l|}{ OLIGOCHAETA } \\
\hline Lumbriculidae & 0 & 0 & 0 & 0 & 0 & 0 & 0 & 0 & 0 & 0 & 0 & 0 & 0 & 0 \\
\hline Haplotaxidae & 0 & 0 & 0 & 16 & 0 & 0 & 0 & 80 & 0 & 0 & 20 & 0 & 0 & 10 \\
\hline Enchytraeidae & 0 & 0 & 12 & 112 & 40 & 160 & 107 & 320 & 48 & 20 & 230 & 480 & 67 & 250 \\
\hline Naididae & 0 & 0 & 0 & 0 & 10020 & 3040 & 0 & 0 & 0 & 0 & 0 & 0 & 0 & 0 \\
\hline TARDIGRADA & 0 & 0 & 0 & 96 & 0 & 160 & 0 & 0 & 0 & 0 & 10 & 0 & 0 & 160 \\
\hline HYDRACHNIDIA & 8 & 4 & 1424 & 48 & 240 & 480 & 1653 & 4320 & 432 & 0 & 0 & 20 & 7 & 100 \\
\hline \multicolumn{15}{|l|}{ CRUSTACEA } \\
\hline Ostracoda & 0 & 0 & 0 & 0 & 0 & 0 & 293 & 240 & 0 & 0 & 10 & 0 & 0 & 0 \\
\hline Copepoda & 0 & 0 & 0 & 96 & 140 & 800 & 4000 & 5680 & 0 & 0 & 180 & 0 & 0 & 0 \\
\hline COLLEMBOLA & 16 & 20 & 0 & 96 & 0 & 0 & 0 & 0 & 48 & 0 & 0 & 0 & 27 & 240 \\
\hline \multicolumn{15}{|l|}{ EPHEMEROPTERA } \\
\hline \multicolumn{15}{|l|}{ Heptagenidae } \\
\hline Rhithrogena juv & 0 & 0 & 0 & 0 & 0 & 0 & 0 & 0 & 0 & 0 & 0 & 0 & 0 & 0 \\
\hline Rhithrogena sp. & 0 & 0 & 0 & 0 & 380 & 0 & 80 & 320 & 32 & 0 & 0 & 0 & 13 & 0 \\
\hline Rhitrogena loyolaea Navàs, 1922 & 0 & 0 & 0 & 0 & 0 & 0 & 0 & 0 & 0 & 0 & 0 & 0 & 0 & 0 \\
\hline $\begin{array}{l}\text { Rhitrogena gr. semicolorata } \\
\text { Baetidae }\end{array}$ & 0 & 0 & 0 & 0 & 0 & 0 & 0 & 0 & 0 & 0 & 0 & 0 & 0 & 0 \\
\hline Baetis alpinus (Pictet, 1834) & 0 & 0 & 0 & 0 & 2500 & 6080 & 5520 & 12560 & 240 & 0 & 0 & 0 & 33 & 60 \\
\hline \multicolumn{15}{|l|}{ PLECOPTERA } \\
\hline Plecoptera juv & 0 & 0 & 0 & 0 & 0 & 160 & 453 & 0 & 0 & 0 & 0 & 0 & 107 & 0 \\
\hline \multicolumn{15}{|l|}{ Perlodidae } \\
\hline Dictyogenus fontium (Ris, 1896) & 0 & 4 & 0 & 0 & 240 & 0 & 53 & 480 & 0 & 0 & 0 & 0 & 53 & 80 \\
\hline $\begin{array}{l}\text { Isoperla cf. rivulorum (Pictet, 1841) } \\
\text { Chloroperlidae }\end{array}$ & 0 & 0 & 0 & 0 & 0 & 0 & 267 & 480 & 0 & 0 & 0 & 0 & 7 & 80 \\
\hline
\end{tabular}




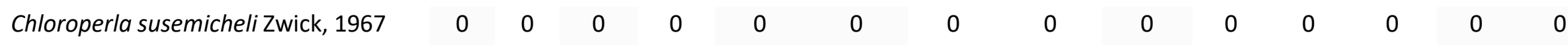

\section{Taeniopterygidae}

$\begin{array}{llllllllllllll}\text { Rhabdiopteryx alpina Kühtreiber, } 1934 & 0 & 0 & 0 & 0 & 40 & 0 & 0 & 0 & 0 & 0 & 0 & 0 & 47\end{array}$

Nemouridae

Protonemura sp.

June 2017

station

$\begin{array}{ccccc}0 & 0 & 0 & 0 & 20 \\ \text { S1 } & \text { S2 } & \text { Z3 } & \text { Z5 } & \text { Z7 }\end{array}$

0

\begin{tabular}{|c|c|c|c|c|c|c|c|c|c|c|c|c|c|c|}
\hline $\begin{array}{l}\text { microhabitat } \\
n^{\circ} \text { replicates }\end{array}$ & $\underset{5}{\min }$ & $\underset{5}{\min }$ & $\underset{5}{\operatorname{mix}}$ & $\underset{5}{\min }$ & $\begin{array}{c}\min \\
4\end{array}$ & $\begin{array}{c}\mathrm{mos} \\
1\end{array}$ & $\min _{3}$ & $\begin{array}{c}\operatorname{mos} \\
2\end{array}$ & $\begin{array}{c}\operatorname{mix} \\
5\end{array}$ & $\begin{array}{c}\text { san } \\
2\end{array}$ & $\begin{array}{c}\text { bou } \\
2\end{array}$ & $\begin{array}{c}\text { mos } \\
1\end{array}$ & $\begin{array}{c}\min \\
3\end{array}$ & $\begin{array}{c}\mathrm{mos} \\
2\end{array}$ \\
\hline Protonemura brevistyla (Ris, 1902) & 0 & 0 & 0 & 0 & 60 & 0 & 267 & 880 & 0 & 0 & 0 & 0 & 0 & 0 \\
\hline Protonemura nitida (Pictet, 1835) & 0 & 0 & 0 & 0 & 120 & 0 & 3013 & 7680 & 48 & 0 & 0 & 0 & 0 & 0 \\
\hline Protonemura cf. lateralis (Pictet, 1835) & 0 & 0 & 0 & 0 & 40 & 160 & 0 & 0 & 0 & 0 & 0 & 0 & 0 & 0 \\
\hline Protonemura nimborum (Ris, 1902) & 0 & 0 & 0 & 0 & 0 & 0 & 320 & 1040 & 304 & 0 & 0 & 0 & 0 & 0 \\
\hline Proronemura cf. caprai (Aubert, 1954) & 0 & 0 & 0 & 0 & 0 & 0 & 0 & 0 & 0 & 0 & 0 & 0 & 0 & 0 \\
\hline Nemoura mortoni (Ris, 1902) & 0 & 0 & 0 & 0 & 1660 & 160 & 240 & 480 & 224 & 0 & 0 & 0 & 240 & 750 \\
\hline Leuctridae & 0 & 0 & 0 & 0 & 0 & 0 & 0 & 0 & 0 & 0 & 0 & 0 & 0 & 0 \\
\hline Leuctridae/Capnidae & 0 & 0 & 0 & 0 & 40 & 0 & 4 & 40 & 0 & 0 & 0 & 0 & 47 & 13 \\
\hline Leuctra major Brink, 1949 & 0 & 0 & 0 & 0 & 240 & 0 & 80 & 0 & 0 & 0 & 0 & 0 & 0 & 0 \\
\hline Leuctra rosinae Kempny, 1900 & 0 & 0 & 0 & 0 & 0 & 0 & 27 & 160 & 320 & 0 & 0 & 0 & 260 & 770 \\
\hline Leuctra cf. teriolensis Kempny, 1900 & 0 & 0 & 0 & 0 & 60 & 0 & 0 & 0 & 0 & 0 & 0 & 0 & 0 & 0 \\
\hline Leuctra braueri Kempny, 1898 & 0 & 0 & 0 & 0 & 0 & 0 & 0 & 0 & 0 & 0 & 0 & 0 & 0 & 0 \\
\hline THYSANOPTERA & 0 & 0 & 0 & 0 & 0 & 0 & 0 & 0 & 0 & 0 & 0 & 0 & 0 & 0 \\
\hline
\end{tabular}

\section{TRICHOPTERA}

\section{Rhyacophilidae}

Rhyacophila intermedia McLachlan, 1868

Rhyacophila pubescens Pictet, 1834

Limpnephilidae

Drusus monticola (McLachlan, 1867)

Drusus cf. adustus (McLachlan, 1867)

Acrophylax zerberus Brauer, 1867

Micropterna lateralis (Stephens, 1837)

$\begin{array}{cccccc}0 & 0 & 0 & 0 & 0 & 0 \\ 0 & 0 & 0 & 0 & 0 & 0 \\ 0 & 0 & 0 & 0 & 0 & 0 \\ 0 & 0 & 0 & 0 & 0 & 0 \\ 0 & 0 & 0 & 0 & 600 & 160 \\ 0 & 0 & 0 & 80 & 20 & 0 \\ 0 & 0 & 0 & 0 & 0 & 0\end{array}$

0
0
0
27
0
27
27

0
0
0
0
80
80
240

16
0
0
0
0
0
0

$\begin{array}{ccccc}0 & 0 & 0 & 0 & 0 \\ 0 & 0 & 0 & 0 & 0 \\ 0 & 0 & 0 & 0 & 0 \\ 0 & 0 & 0 & 33 & 430 \\ 0 & 0 & 0 & 1333 & 2800 \\ 100 & 30 & 220 & 0 & 0 \\ 0 & 0 & 0 & 0 & 0\end{array}$


Drusus discolor (Rambur, 1842)

\section{Goeridae}

Lithax niger (Hagen, 1859)

\section{COLEOPTERA}

Coleoptera.

Elminthidae

\section{DIPTERA}

Tipulidae

Limoniidae

Pediciidae

Simuliidae

Ceratopogonidae

June 2017

station

$\begin{array}{lllllllllllll}0 & 0 & 0 & 0 & 0 & 0 & 0 & 0 & 64 & 0 & 0 & 0 & 0\end{array}$

(a)

(n)

microhabitat $\min \min \operatorname{mix} \min \min \operatorname{mos} \min \operatorname{mos} \operatorname{mix}$ san bou mos min mos

\section{Chironomidae \\ Diamesinae}

Diamesa

Pseudodiamesa

Pseudokiefferiella

Boreoheptagyia

Orthocladiinae

Chironominae

Tanytarsini

Chironomini

Tanypodinae

Psychodidae

Blephariceridae

Empididae

Dolichopodidae

Muscidae (Lispe)

$n^{\circ}$ replicates

\begin{tabular}{llllllllllllll}
5 & 5 & 5 & 5 & 4 & 1 & 3 & 2 & 5 & 2 & 2 & 1 & 3 & 2 \\
\hline
\end{tabular}


Dixidae

Thaumaleidae

MOLLUSCA - Planorbidae

Gyraulus

$\begin{array}{llllllllllllll}0 & 0 & 0 & 0 & 0 & 0 & 0 & 0 & 16 & 0 & 0 & 0 & 0 & 0 \\ 0 & 0 & 0 & 0 & 0 & 0 & 0 & 80 & 0 & 0 & 0 & 0 & 0 & 0 \\ 0 & 0 & 0 & 0 & 0 & 0 & 0 & 0 & 0 & 0 & 0 & 0 & 0 & 0\end{array}$




\begin{tabular}{|c|c|c|c|c|c|c|c|c|c|c|c|c|c|c|c|c|c|c|}
\hline $\begin{array}{c}\text { station } \\
\text { Microhabitat } \\
\mathrm{n}^{\circ} \text { replicates }\end{array}$ & $\begin{array}{c}\text { S1 } \\
\min \\
5 \\
\end{array}$ & $\begin{array}{c}\text { S2 } \\
\min \\
5 \\
\end{array}$ & $\begin{array}{c}\mathbf{Z 1} \\
\min \\
5 \\
\end{array}$ & $\begin{array}{c}\mathbf{Z 3} \\
\min \\
5 \\
\end{array}$ & $\begin{array}{c}\mathbf{Z 4} \\
\min \\
4 \\
\end{array}$ & $\begin{array}{c}\mathbf{Z 4} \\
\text { moss } \\
1 \\
\end{array}$ & $\begin{array}{c}\mathbf{Z 5} \\
\min \\
5 \\
\end{array}$ & $\begin{array}{c}\mathbf{Z 7} \\
\min \\
3 \\
\end{array}$ & $\begin{array}{c}\mathbf{Z 7} \\
\text { mos } \\
2 \\
\end{array}$ & $\begin{array}{c}\text { ZKN } \\
\min \\
4 \\
\end{array}$ & $\begin{array}{c}\text { ZKN } \\
\text { mos } \\
1 \\
\end{array}$ & $\begin{array}{c}\text { SKN } \\
\min \\
4 \\
\end{array}$ & $\begin{array}{c}\text { SKN } \\
\text { mos } \\
1 \\
\end{array}$ & $\begin{array}{c}\text { ZRG } \\
\text { san } \\
2 \\
\end{array}$ & $\begin{array}{c}\text { ZRG } \\
\text { mos } \\
1 \\
\end{array}$ & $\begin{array}{c}\text { ZRG } \\
\min \\
2 \\
\end{array}$ & $\begin{array}{c}\text { SRG } \\
\min \\
3 \\
\end{array}$ & $\begin{array}{c}\text { SRG } \\
\text { mos } \\
2 \\
\end{array}$ \\
\hline \multicolumn{19}{|l|}{ TURBELLARIA } \\
\hline Crenobia alpina (Dana, 1766) & 0 & 0 & 0 & 0 & 0 & 0 & 0 & 0 & 0 & 0 & 0 & 0 & 480 & 0 & 0 & 0 & 0 & 0 \\
\hline NEMATODA & 8 & 0 & 0 & 60 & 300 & 1280 & 5600 & 8213 & 11800 & 5080 & 2800 & 400 & 3840 & 81840 & 30720 & 8080 & 1067 & 800 \\
\hline \multicolumn{19}{|l|}{ OLIGOCHAETA } \\
\hline Lumbriculidae & 0 & 0 & 0 & 0 & 0 & 0 & 0 & 0 & 0 & 0 & 0 & 0 & 0 & 0 & 0 & 0 & 0 & 0 \\
\hline Haplotaxidae & 0 & 0 & 0 & 0 & 40 & 0 & 32 & 160 & 0 & 0 & 0 & 0 & 160 & 0 & 0 & 0 & 27 & 0 \\
\hline Enchytraeidae & 0 & 0 & 0 & 0 & 20 & 320 & 80 & 533 & 400 & 2080 & 240 & 0 & 480 & 160 & 5760 & 5120 & 800 & 160 \\
\hline Naididae & 0 & 0 & 0 & 0 & 0 & 0 & 0 & 4747 & 4360 & 0 & 0 & 0 & 0 & 0 & 0 & 0 & 0 & 80 \\
\hline TARDIGRADA & 56 & 16 & 0 & 0 & 0 & 320 & 0 & 107 & 960 & 0 & 0 & 0 & 0 & 1840 & 19360 & 8320 & 133 & 320 \\
\hline HYDRACHNIDIA & 8 & 0 & 0 & 4 & 0 & 0 & 0 & 533 & 600 & 400 & 720 & 360 & 4640 & 0 & 1120 & 400 & 53 & 0 \\
\hline \multicolumn{19}{|l|}{ CRUSTACEA } \\
\hline Ostracoda & 0 & 0 & 0 & 4 & 0 & 0 & 0 & 53 & 0 & 200 & 160 & 40 & 0 & 0 & 0 & 0 & 0 & 0 \\
\hline Copepoda & 88 & 48 & 0 & 20 & 0 & 0 & 576 & 587 & 1040 & 2520 & 5760 & 1160 & 320 & 0 & 68160 & 2800 & 107 & 0 \\
\hline COLLEMBOLA & 0 & 0 & 48 & 92 & 20 & 1760 & 512 & 107 & 0 & 0 & 0 & 200 & 0 & 0 & 320 & 0 & 53 & 80 \\
\hline \multicolumn{19}{|l|}{ EPHEMEROPTERA } \\
\hline \multicolumn{19}{|l|}{ Heptagenidae } \\
\hline Rhithrogena juv & 0 & 0 & 0 & 0 & 0 & 0 & 0 & 693 & 0 & 0 & 0 & 368 & 0 & 0 & 0 & 0 & 0 & 0 \\
\hline Rhithrogena sp. & 0 & 0 & 0 & 0 & 0 & 0 & 0 & 213 & 0 & 0 & 0 & 240 & 160 & 0 & 0 & 0 & 0 & 0 \\
\hline Rhitrogena loyolaea Navàs, 1922 & 0 & 0 & 0 & 0 & 0 & 0 & 0 & 0 & 0 & 600 & 0 & 480 & 0 & 0 & 0 & 0 & 0 & 0 \\
\hline Rhitrogena gr. Semicolorata & 0 & 0 & 0 & 0 & 0 & 0 & 0 & 0 & 0 & 80 & 0 & 120 & 0 & 0 & 0 & 0 & 0 & 0 \\
\hline \multicolumn{19}{|l|}{ Baetidae } \\
\hline Baetis alpinus (Pictet, 1834) & 0 & 0 & 0 & 0 & 0 & 0 & 176 & 15147 & 6240 & 760 & 1040 & 520 & 4960 & 0 & 0 & 0 & 293 & 320 \\
\hline \multicolumn{19}{|l|}{ PLECOPTERA } \\
\hline Plecoptera juv & 0 & 0 & 8 & 0 & 0 & 0 & 0 & 0 & 0 & 0 & 0 & 0 & 0 & 0 & 0 & 0 & 0 & 0 \\
\hline \multicolumn{19}{|l|}{ Perlodidae } \\
\hline Dictyogenus fontium (Ris, 1896) & 0 & 0 & 0 & 0 & 0 & 0 & 16 & 640 & 0 & 160 & 0 & 40 & 0 & 0 & 0 & 0 & 53 & 240 \\
\hline Isoperla cf. rivulorum (Pictet, 1841) & 0 & 0 & 0 & 0 & 0 & 0 & 0 & 0 & 0 & 200 & 160 & 0 & 0 & 0 & 0 & 0 & 0 & 0 \\
\hline \multicolumn{19}{|l|}{ Chloroperlidae } \\
\hline Chloroperla susemicheli Zwick, 1967 & 0 & 0 & 0 & 0 & 0 & 0 & 0 & 0 & 0 & 0 & 0 & 0 & 0 & 0 & 0 & 0 & 0 & 0 \\
\hline
\end{tabular}


Taeniopterygidae

Rhabdiopteryx alpina Kühtreiber, 1934

\section{Nemouridae}

Protonemura sp.

$0 \quad 8$

Protonemura brevistyla (Ris, 1902)

August 2017

station

Microhabitat $\begin{array}{lllll}0 & 0 & 0 & 0 & 0 \\ 0 & 0 & 0 & 0 & 0\end{array}$

Protonemura nitida (Pictet, 1835)
Protonemura cf. lateralis (Pictet, 1835)

Protonemura nimborum (Ris, 1902)

Proronemura cf. caprai (Aubert, 1954)

Nemoura mortoni (Ris, 1902)

\section{Leuctridae}

Leuctridae/Capnidae

Leuctra major Brink, 1949

Leuctra rosinae Kempny, 1900

Leuctra cf. teriolensis Kempny, 1900

Leuctra braueri Kempny, 1898

\section{THYSANOPTERA}

\section{PTERA}

\section{Rhyacophilidae}

Rhyacophila intermedia McLachlan, 1868

Rhyacophila pubescens Pictet, 1834

\section{Limpnephilidae}

Drusus monticola (McLachlan, 1867)

Drusus cf. adustus (McLachlan, 1867)

Acrophylax zerberus Brauer, 1867

Micropterna lateralis (Stephens, 1837)

Drusus discolor (Rambur, 1842)

\section{Goeridae}

Lithax niger (Hagen, 1859)

\begin{tabular}{|c|c|c|c|c|c|c|c|c|c|c|c|c|c|c|c|c|c|}
\hline 0 & 0 & 0 & 0 & 0 & 0 & 0 & 107 & 40 & 80 & 160 & 0 & 480 & 0 & 0 & 0 & 0 & 0 \\
\hline S1 & S2 & Z1 & Z3 & Z4 & Z4 & $\mathrm{Z5}$ & $\mathrm{Z7}$ & $\mathbf{Z 7}$ & ZKN & ZKN & SKN & SKN & ZRG & ZRG & ZRG & SRG & SRG \\
\hline $\min$ & $\min$ & $\min$ & $\min$ & $\min$ & moss & $\min$ & $\min$ & mos & $\min$ & mos & $\min$ & mos & san & mos & $\min$ & $\min$ & mos \\
\hline
\end{tabular}

$\begin{array}{lllll}5 & 5 & 5 & 5 & 4 \\ 0 & 0 & 0 & 0 & 0 \\ 0 & 0 & 0 & 0 & 0 \\ 0 & 0 & 0 & 0 & 0 \\ 0 & 0 & 0 & 0 & 0 \\ 0 & 0 & 0 & 0 & 0 \\ 0 & 0 & 0 & 0 & 0 \\ 0 & 0 & 0 & 0 & 0 \\ 0 & 0 & 0 & 0 & 0 \\ 0 & 0 & 0 & 0 & 0 \\ 0 & 0 & 0 & 0 & 0 \\ 0 & 0 & 0 & 0 & 0 \\ 8 & 0 & 4 & 0 & 0\end{array}$

1
0
0
0
0
0
0
0
0
0
0
0
0

$\begin{array}{cc}5 & \\ 16 & 267 \\ 0 \\ 0 \\ 0 \\ 0 \\ 0 \\ 0 \\ 0 \\ 0 \\ 0 \\ 0 \\ 16\end{array}$

3
267
0
0
0
693
0
25
53
0
0
0
0

2
0
0
0
0
40
0
0
0
0
0
0
80

4
1000
0
0
0
200
0
40
80
40
0
0
40

1
1680
0
160
0
800
0
40
0
160
0
0
80

$\begin{array}{llllll}0 & 0 & 0 & 0 & 0 & 0 \\ 0 & 0 & 0 & 0 & 0 & 0 \\ 0 & 0 & 0 & 0 & 0 & 0 \\ 0 & 0 & 0 & 0 & 0 & 0 \\ 0 & 0 & 0 & 0 & 0 & 0 \\ 0 & 0 & 0 & 0 & 220 & 0 \\ 0 & 0 & 0 & 0 & 0 & 0 \\ 0 & 0 & 0 & 0 & 0 & 0\end{array}$

$\begin{array}{cc}0 & 0 \\ 0 & 0 \\ 0 & 0 \\ 0 & 0 \\ 16 & 747 \\ 80 & 0 \\ 0 & 0 \\ 0 & 0\end{array}$

0
0
0
0
40
0
0
0

0
0
0
0
40
0
80
0

$\begin{array}{cccccccc}0 & 0 & 160 & 0 & 0 & 0 & 0 & 0 \\ 0 & 0 & 320 & 0 & 0 & 0 & 0 & 0 \\ 0 & 0 & 0 & 0 & 0 & 0 & 0 & 0 \\ 0 & 0 & 0 & 0 & 0 & 0 & 53 & 400 \\ 0 & 40 & 0 & 0 & 0 & 0 & 1680 & 3600 \\ 0 & 0 & 0 & 320 & 480 & 80 & 0 & 0 \\ 0 & 40 & 0 & 0 & 0 & 0 & 0 & 0 \\ 0 & 0 & 320 & 0 & 0 & 0 & 0 & 0 \\ 80 & 0 & 0 & 0 & 0 & 0 & 0 & 0\end{array}$


COLEOPTERA

Coleoptera

Elminthidae

\section{DIPTERA}

Tipulidae

Limoniidae

Pediciidae

Simuliidae

Ceratopogonidae

$\begin{array}{cccc}0 & 0 & 0 & 0 \\ 0 & 0 & 0 & 0 \\ 0 & 0 & 0 & 0 \\ 0 & 0 & 0 & 0 \\ 0 & 0 & 0 & 20 \\ 0 & 0 & 0 & 0 \\ 0 & 0 & 0 & 0 \\ 0 & 0 & 0 & 0\end{array}$

\begin{tabular}{l} 
Chironomidae \\
\hline August 2017
\end{tabular}

\begin{tabular}{|c|c|c|c|c|c|c|c|c|c|c|c|c|c|c|c|c|c|c|c|}
\hline August 2017 & $\begin{array}{c}\text { station } \\
\text { Microhabitat } \\
\mathrm{n}^{\circ} \text { replicates }\end{array}$ & $\begin{array}{c}\text { S1 } \\
\min \\
5\end{array}$ & $\begin{array}{c}\text { S2 } \\
\min \\
5\end{array}$ & $\begin{array}{c}\mathrm{Z1} \\
\min \\
5\end{array}$ & $\begin{array}{c}\mathbf{Z 3} \\
\min \\
5\end{array}$ & $\begin{array}{c}\text { Z4 } \\
\min \\
4\end{array}$ & $\begin{array}{c}\mathbf{Z 4} \\
\text { moss } \\
1 \\
\end{array}$ & $\begin{array}{c}\mathbf{Z 5} \\
\min \\
5\end{array}$ & $\begin{array}{c}\mathbf{2 7} \\
\min \\
3 \\
\end{array}$ & $\begin{array}{c}\text { Z7 } \\
\text { mos } \\
2 \\
\end{array}$ & $\begin{array}{c}\text { ZKN } \\
\min \\
4\end{array}$ & $\begin{array}{c}\text { ZKN } \\
\text { mos } \\
1 \\
\end{array}$ & $\begin{array}{c}\text { SKN } \\
\min \\
4\end{array}$ & $\begin{array}{c}\text { SKN } \\
\text { mos } \\
1 \\
\end{array}$ & $\begin{array}{c}\text { ZRG } \\
\text { san } \\
2 \\
\end{array}$ & $\begin{array}{c}\text { ZRG } \\
\text { mos } \\
1\end{array}$ & $\begin{array}{c}\text { ZRG } \\
\min \\
2 \\
\end{array}$ & $\begin{array}{c}\text { SRG } \\
\min \\
3\end{array}$ & $\begin{array}{c}\text { SRG } \\
\text { mos } \\
2 \\
\end{array}$ \\
\hline \multicolumn{20}{|l|}{ Diamesinae } \\
\hline Diamesa & & 8 & 1568 & 188 & 1260 & 7800 & 19840 & 3664 & 14313 & 563 & 403 & 936 & 186 & 0 & 0 & 0 & 0 & 2453 & 8480 \\
\hline Pseudodiamesa & & 0 & 0 & 0 & 0 & 0 & 1920 & 704 & 0 & 0 & 0 & 0 & 0 & 0 & 3120 & 2880 & 3280 & 0 & 0 \\
\hline Pseudokiefferiella & & 0 & 0 & 0 & 0 & 0 & 0 & 0 & 3340 & 11258 & 0 & 0 & 0 & 0 & 0 & 0 & 0 & 160 & 3360 \\
\hline Boreoheptagyia & & 0 & 0 & 0 & 0 & 0 & 0 & 0 & 0 & 0 & 0 & 0 & 0 & 0 & 0 & 0 & 0 & 0 & 0 \\
\hline Orthocladiinae & & 0 & 40 & 0 & 92 & 280 & 3200 & 192 & 95420 & 73175 & 20129 & 35083 & 5092 & 98560 & 640 & 3360 & 0 & 4427 & 22160 \\
\hline Chironominae & & 0 & 0 & 0 & 0 & 0 & 0 & 0 & 0 & 0 & 0 & 0 & 0 & 0 & 0 & 0 & 0 & 0 & 0 \\
\hline Tanytarsini & & 0 & 0 & 0 & 0 & 0 & 0 & 0 & 954 & 844 & 268 & 702 & 1118 & 2880 & 0 & 640 & 0 & 0 & 0 \\
\hline Chironomini & & 0 & 0 & 0 & 0 & 0 & 0 & 0 & 0 & 0 & 0 & 0 & 0 & 0 & 0 & 0 & 0 & 0 & 0 \\
\hline Tanypodinae & & 0 & 0 & 0 & 0 & 0 & 0 & 0 & 0 & 0 & 0 & 0 & 124 & 0 & 0 & 0 & 0 & 0 & 0 \\
\hline Psychodidae & & 0 & 0 & 0 & 0 & 0 & 0 & 0 & 0 & 0 & 0 & 0 & 0 & 0 & 0 & 0 & 0 & 0 & 0 \\
\hline Blephariceridae & & 0 & 0 & 0 & 0 & 0 & 0 & 0 & 0 & 0 & 0 & 0 & 0 & 0 & 0 & 0 & 0 & 0 & 0 \\
\hline Empididae & & 0 & 8 & 0 & 0 & 0 & 0 & 0 & 160 & 80 & 0 & 0 & 0 & 0 & 0 & 0 & 0 & 80 & 80 \\
\hline Dolichopodidae & & 0 & 0 & 0 & 0 & 0 & 0 & 0 & 0 & 0 & 0 & 0 & 0 & 0 & 0 & 0 & 0 & 0 & 0 \\
\hline Muscidae (Lispe) & & 0 & 0 & 0 & 0 & 20 & 0 & 0 & 53 & 0 & 0 & 0 & 0 & 0 & 0 & 0 & 0 & 0 & 0 \\
\hline Dixidae & & 0 & 0 & 0 & 0 & 0 & 0 & 0 & 0 & 0 & 0 & 0 & 0 & 0 & 0 & 0 & 0 & 0 & 0 \\
\hline Thaumaleidae & & 0 & 0 & 0 & 0 & 0 & 0 & 0 & 0 & 0 & 0 & 0 & 120 & 0 & 0 & 0 & 0 & 0 & 0 \\
\hline \multicolumn{20}{|c|}{ MOLLUSCA - Planorbidae } \\
\hline Gyraulus & & 0 & 0 & 0 & 0 & 0 & 0 & 0 & 0 & 0 & 0 & 0 & 0 & 0 & 0 & 0 & 0 & 0 & 0 \\
\hline
\end{tabular}

43

0
0
0
0
0
0
0
0

0
0
0
0
0
0
16
0

$\begin{array}{ccc}0 & 0 & 0 \\ 0 & 0 & 0 \\ 0 & 0 & 0 \\ 0 & 0 & 0 \\ 0 & 40 & 120 \\ 107 & 0 & 40 \\ 0 & 40 & 40 \\ 0 & 0 & 80\end{array}$

$\begin{array}{cc}0 & 0 \\ 0 & 0 \\ 0 & 0 \\ 0 & 0 \\ 80 & 40 \\ 0 & 0 \\ 0 & 40 \\ 0 & 240\end{array}$

0
0
0
0
0
0
0
0

0
0
0
0
0
0
0
0

$\begin{array}{ccc}0 & 0 & 0 \\ 0 & 0 & 0 \\ 0 & 0 & 0 \\ 0 & 0 & 0 \\ 160 & 0 & 53 \\ 0 & 80 & 107 \\ 0 & 0 & 0 \\ 0 & 0 & 27\end{array}$

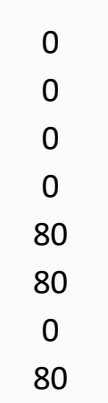





\begin{tabular}{|c|c|c|c|c|c|c|c|c|c|c|c|c|c|c|c|c|c|}
\hline $\begin{array}{r}\text { station } \\
\text { microhabitat } \\
\mathrm{n}^{\circ} \text { replicates }\end{array}$ & $\begin{array}{c}\text { S1 } \\
\min \\
5 \\
\end{array}$ & $\begin{array}{c}\mathbf{S 2} \\
\min \\
5 \\
\end{array}$ & $\begin{array}{c}\mathbf{Z 1} \\
\min \\
4 \\
\end{array}$ & $\begin{array}{c}\mathbf{Z 1} \\
\text { Hyd } \\
1 \\
\end{array}$ & $\begin{array}{c}3 \\
\min \\
5 \\
\end{array}$ & $\begin{array}{c}\mathbf{Z 4} \\
\min \\
5 \\
\end{array}$ & $\begin{array}{c}\mathbf{Z 5} \\
\min \\
5 \\
\end{array}$ & $\begin{array}{c}\mathbf{Z 7} \\
\min \\
3 \\
\end{array}$ & $\begin{array}{c}\mathrm{Z7} \\
\mathrm{mos} \\
2 \\
\end{array}$ & $\begin{array}{c}\text { ZKN } \\
\min \\
4 \\
\end{array}$ & $\begin{array}{c}\text { ZKN } \\
\text { mos } \\
1 \\
\end{array}$ & $\begin{array}{c}\text { SKN } \\
\min \\
4 \\
\end{array}$ & $\begin{array}{c}\text { SKN } \\
\text { mos } \\
1 \\
\end{array}$ & $\begin{array}{c}\text { ZRG } \\
\text { bou } \\
1 \\
\end{array}$ & $\begin{array}{c}\text { ZRG } \\
\text { san } \\
4 \\
\end{array}$ & $\begin{array}{c}\text { SRG } \\
\min \\
3 \\
\end{array}$ & $\begin{array}{c}\text { SRG } \\
\text { mos } \\
2 \\
\end{array}$ \\
\hline \multicolumn{18}{|l|}{ TURBELLARIA } \\
\hline Crenobia alpina (Dana, 1766) & 0 & 0 & 0 & 0 & 0 & 0 & 0 & 0 & 0 & 0 & 80 & 940 & 160 & 0 & 0 & 0 & 0 \\
\hline NEMATODA & 20 & 4 & 0 & 0 & 0 & 0 & 5616 & 53 & 0 & 360 & 160 & 80 & 3360 & 1100 & 7300 & 0 & 0 \\
\hline \multicolumn{18}{|l|}{ OLIGOCHAETA } \\
\hline Lumbriculidae & 0 & 0 & 0 & 0 & 0 & 0 & 0 & 0 & 0 & 0 & 0 & 0 & 0 & 0 & 0 & 0 & 0 \\
\hline Haplotaxidae & 0 & 0 & 0 & 0 & 0 & 0 & 0 & 0 & 0 & 0 & 0 & 0 & 0 & 0 & 0 & 27 & 0 \\
\hline Enchytraeidae & 4 & 0 & 0 & 0 & 0 & 32 & 928 & 373 & 4640 & 680 & 320 & 0 & 480 & 80 & 40 & 80 & 240 \\
\hline Naididae & 0 & 0 & 0 & 0 & 0 & 0 & 0 & 4480 & 13600 & 0 & 0 & 0 & 0 & 0 & 0 & 0 & 0 \\
\hline TARDIGRADA & 4 & 0 & 0 & 0 & 0 & 0 & 16 & 0 & 80 & 0 & 80 & 0 & 480 & 80 & 300 & 0 & 400 \\
\hline HYDRACHNIDIA & 4 & 4 & 0 & 40 & 0 & 0 & 16 & 160 & 480 & 720 & 3840 & 340 & 12480 & 0 & 0 & 27 & 80 \\
\hline \multicolumn{18}{|l|}{ CRUSTACEA } \\
\hline Ostracoda & 0 & 0 & 0 & 0 & 0 & 0 & 0 & 0 & 0 & 360 & 160 & 0 & 0 & 0 & 0 & 0 & 0 \\
\hline Copepoda & 232 & 4 & 0 & 0 & 0 & 0 & 256 & 53 & 320 & 3120 & 7920 & 6860 & 40000 & 67900 & 2620 & 53 & 480 \\
\hline COLLEMBOLA & 4 & 0 & 60 & 0 & 80 & 0 & 16 & 107 & 0 & 0 & 80 & 60 & 640 & 60 & 0 & 0 & 160 \\
\hline \multicolumn{18}{|l|}{ EPHEMEROPTERA } \\
\hline \multicolumn{18}{|l|}{ Heptagenidae } \\
\hline Rhithrogena juv & 0 & 0 & 0 & 0 & 0 & 0 & 0 & 0 & 0 & 36 & 0 & 0 & 0 & 0 & 0 & 0 & 0 \\
\hline Rhithrogena sp. & 0 & 0 & 0 & 0 & 0 & 16 & 0 & 0 & 0 & 0 & 0 & 60 & 0 & 0 & 0 & 27 & 0 \\
\hline Rhitrogena loyolaea Navàs, 1922 & 0 & 0 & 0 & 0 & 0 & 0 & 0 & 0 & 0 & 280 & 0 & 140 & 0 & 0 & 0 & 0 & 0 \\
\hline Rhitrogena gr. semicolorata & 0 & 0 & 0 & 0 & 0 & 0 & 0 & 0 & 0 & 80 & 0 & 60 & 0 & 0 & 0 & 0 & 0 \\
\hline \multicolumn{18}{|l|}{ Baetidae } \\
\hline Baetis alpinus (Pictet, 1834) & 0 & 0 & 0 & 0 & 0 & 16 & 224 & 15787 & 47040 & 800 & 4000 & 800 & 3520 & 0 & 0 & 187 & 880 \\
\hline \multicolumn{18}{|l|}{ PLECOPTERA } \\
\hline Plecoptera juv & 4 & 0 & 0 & 0 & 0 & 0 & 0 & 160 & 0 & 0 & 240 & 7080 & 2560 & 0 & 0 & 0 & 0 \\
\hline \multicolumn{18}{|l|}{ Perlodidae } \\
\hline Dictyogenus fontium (Ris, 1896) & 0 & 0 & 0 & 0 & 0 & 16 & 0 & 320 & 80 & 160 & 480 & 20 & 160 & 0 & 0 & 107 & 640 \\
\hline Isoperla cf. rivulorum (Pictet, 1841) & 0 & 0 & 0 & 0 & 0 & 0 & 0 & 0 & 0 & 120 & 480 & 0 & 480 & 0 & 0 & 27 & 240 \\
\hline \multicolumn{18}{|l|}{ Chloroperlidae } \\
\hline Chloroperla susemicheli Zwick, 1967 & 0 & 0 & 0 & 0 & 0 & 0 & 0 & 0 & 0 & 0 & 0 & 0 & 0 & 0 & 0 & 0 & 0 \\
\hline
\end{tabular}


Taeniopterygidae

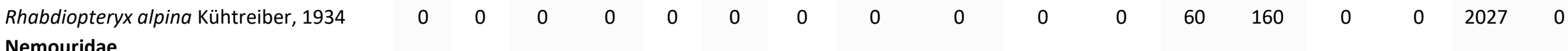

Protonemura sp.

$\begin{array}{llllllll}0 & 0 & 0 & 0 & 0 & 0 & 0 & 27\end{array}$

Protonemura brevistyla (Ris, 1902)

September 2017

$\begin{array}{ccc}0 & 0 & 0 \\ \text { S1 } & \text { S2 } & \text { Z1 }\end{array}$

$\begin{array}{cccccccccccccc}0 & 0 & 0 & 0 & 0 & 160 & 80 & 160 & 160 & 480 & 0 & 0 & 0 & 0 \\ \text { Z1 } & \text { Z3 } & \text { Z4 } & \text { Z5 } & \text { Z7 } & \text { Z7 } & \text { ZKN } & \text { ZKN } & \text { SKN } & \text { SKN } & \text { ZRG } & \text { ZRG } & \text { SRG } & \text { SRG } \\ \text { Hyd } & \min & \min & \min & \min & \text { mos } & \text { min } & \text { mos } & \text { min } & \text { mos } & \text { bou } & \text { san } & \text { min } & \text { mos }\end{array}$

Protonemura nitida (Pictet, 1835) microhabitat $\min \min \min$

Protonemura cf. lateralis (Pictet, 1835)

Protonemura nimborum (Ris, 1902)

Proronemura cf. caprai (Aubert, 1954)

Nemoura mortoni (Ris, 1902)

\section{Leuctridae}

Leuctridae/Capnidae

Leuctra major Brink, 1949

Leuctra rosinae Kempny, 1900

Leuctra cf. teriolensis Kempny, 1900

Leuctra braueri Kempny, 1898

\section{THYSANOPTERA}

\section{TRICHOPTERA}

\section{Rhyacophilidae}

Rhyacophila intermedia McLachlan, 1868

Rhyacophila pubescens Pictet, 1834

\section{Limpnephilidae}

Drusus monticola (McLachlan, 1867)

Drusus cf. adustus (McLachlan, 1867)

Acrophylax zerberus Brauer, 1867

Micropterna lateralis (Stephens, 1837)

Drusus discolor (Rambur, 1842)

Goeridae

Lithax niger (Hagen, 1859)

$\begin{array}{cccccc}5 & 5 & 4 & 1 & 5 & 5 \\ 0 & 0 & 0 & 0 & 0 & 0 \\ 0 & 0 & 0 & 0 & 0 & 0 \\ 0 & 0 & 0 & 0 & 0 & 0 \\ 0 & 0 & 0 & 0 & 0 & 0 \\ 0 & 52 & 0 & 0 & 0 & 16 \\ 0 & 0 & 0 & 0 & 0 & 0 \\ 0 & 0 & 0 & 0 & 0 & 0 \\ 0 & 0 & 0 & 0 & 0 & 0 \\ 0 & 0 & 0 & 0 & 0 & 0 \\ 0 & 0 & 0 & 0 & 0 & 0 \\ 0 & 0 & 0 & 0 & 0 & 0 \\ 0 & 0 & 0 & 0 & 0 & 0\end{array}$

$\begin{array}{ll}5 & 1 \\ 0 & 107 \\ 0 & \\ 0 & \\ 0 & \\ 0 & 160 \\ 0 & 53 \\ 0 & 53 \\ 0 & 53 \\ 0 & \\ 0 & \\ 0 & \\ 0 & \end{array}$

3
107
0
0
0
1600
53
53
53
0
0
0
0

20

148054

0

0
0

0
1440

320

$80 \quad 0$

80

$0 \quad 320$

320

400

$5440 \quad 160$

1120

$\begin{array}{lll}0 & 340 & 2720\end{array}$

$\begin{array}{lll}4 & 3 & 2 \\ 0 & 0 & 0\end{array}$

0

0
0

$\begin{array}{cccccccc}0 & 0 & 0 & 0 & 0 & 0 & 0 & 0 \\ 0 & 0 & 0 & 0 & 0 & 0 & 0 & 0 \\ 0 & 0 & 0 & 0 & 0 & 0 & 0 & 0 \\ 0 & 0 & 0 & 0 & 0 & 0 & 0 & 0 \\ 0 & 0 & 0 & 0 & 0 & 0 & 16 & 800 \\ 0 & 0 & 0 & 0 & 0 & 256 & 240 & 107 \\ 0 & 0 & 0 & 0 & 0 & 0 & 0 & 0 \\ 0 & 0 & 0 & 0 & 0 & 0 & 0 & 0\end{array}$

0
0
0
0
1040
0
0
0

$\begin{array}{cccc}0 & 80 & 0 & 0 \\ 0 & 0 & 40 & 0 \\ 0 & 0 & 0 & 0 \\ 0 & 0 & 0 & 0 \\ 120 & 0 & 100 & 320 \\ 200 & 1440 & 0 & 0 \\ 200 & 0 & 0 & 320 \\ 0 & 0 & 120 & 160\end{array}$

$\begin{array}{cccc}0 & 0 & 0 & 0 \\ 0 & 0 & 0 & 0 \\ 0 & 0 & 0 & 0 \\ 0 & 0 & 240 & 0 \\ 0 & 0 & 1093 & 240 \\ 60 & 80 & 0 & 0 \\ 0 & 0 & 0 & 0 \\ 0 & 0 & 0 & 0\end{array}$

0

0

$0 \quad 0$

$0 \quad 0$

$0 \quad 0 \quad 760$

80

0 
COLEOPTERA

Coleoptera

Elminthidae

DIPTERA

Tipulidae

Limoniidae

Pediciidae

Simuliidae

Ceratopogonidae

Chironomidae

September 2017

$\begin{array}{ll}0 & 0 \\ 0 & 0 \\ 0 & 0 \\ 0 & 0 \\ 0 & 68 \\ 0 & 0 \\ 0 & 0 \\ 0 & 0\end{array}$

$\begin{array}{ll}0 & 0 \\ 0 & 0 \\ 0 & 0 \\ 0 & 0 \\ 0 & 0 \\ 0 & 0 \\ 0 & 0 \\ 0 & 0\end{array}$

$\begin{array}{lc}0 & 0 \\ 0 & 0 \\ 0 & 0 \\ 0 & 0 \\ 0 & 16 \\ 0 & 0 \\ 0 & 0 \\ 0 & 0\end{array}$

$\begin{array}{cc}0 & 0 \\ 0 & 0 \\ 0 & 0 \\ 0 & 0 \\ 0 & 0 \\ 32 & 0 \\ 0 & 53 \\ 0 & 0\end{array}$

0
0
0
0
0
0
0
0

$\begin{array}{ccc}0 & 0 & 0 \\ 0 & 0 & 0 \\ 0 & 0 & 0 \\ 0 & 0 & 0 \\ 80 & 0 & 0 \\ 0 & 160 & 60 \\ 0 & 400 & 80 \\ 0 & 0 & 0\end{array}$

$\begin{array}{ccccc}0 & 0 & 0 & 0 & 0 \\ 0 & 0 & 0 & 0 & 0 \\ 0 & 0 & 0 & 0 & 0 \\ 0 & 0 & 0 & 0 & 0 \\ 0 & 0 & 0 & 187 & 160 \\ 0 & 0 & 0 & 0 & 0 \\ 0 & 0 & 0 & 0 & 0 \\ 0 & 0 & 0 & 0 & 0\end{array}$

\begin{tabular}{|c|c|c|c|c|c|c|c|c|c|c|c|c|c|c|c|c|c|c|}
\hline September 2017 & $\begin{array}{l}\text { station } \\
\text { microhabitat } \\
\mathrm{n}^{\circ} \text { replicates }\end{array}$ & $\begin{array}{c}\text { S1 } \\
\min \\
5\end{array}$ & $\begin{array}{c}\text { S2 } \\
\min \\
5\end{array}$ & $\begin{array}{c}\mathrm{Z1} \\
\min \\
4\end{array}$ & $\begin{array}{l}\text { Z1 } \\
\text { Hyd } \\
1\end{array}$ & $\begin{array}{c}\mathrm{Z3} \\
\min \\
5\end{array}$ & $\begin{array}{c}\mathbf{Z 4} \\
\min \\
5\end{array}$ & $\begin{array}{c}\mathbf{Z 5} \\
\min \\
5\end{array}$ & $\begin{array}{c}\mathbf{z 7} \\
\min \\
3\end{array}$ & $\begin{array}{c}\mathbf{Z 7} \\
\text { mos } \\
2\end{array}$ & $\begin{array}{c}\text { ZKN } \\
\min \\
4\end{array}$ & $\begin{array}{c}\text { ZKN } \\
\text { mos } \\
1\end{array}$ & $\begin{array}{c}\text { SKN } \\
\min \\
4\end{array}$ & $\begin{array}{c}\text { SKN } \\
\text { mos } \\
1\end{array}$ & $\begin{array}{c}\text { ZRG } \\
\text { bou } \\
1\end{array}$ & $\begin{array}{c}\text { ZRG } \\
\text { san } \\
4\end{array}$ & $\begin{array}{l}\text { SRG } \\
\min \\
3\end{array}$ & $\begin{array}{l}\text { SRG } \\
\text { mos } \\
2\end{array}$ \\
\hline \multicolumn{19}{|l|}{ Diamesinae } \\
\hline Diamesa & & 20 & 784 & 1610 & 6800 & 920 & 1808 & 320 & 587 & 0 & 420 & 251 & 143 & 0 & 0 & 0 & 133 & 880 \\
\hline Pseudodiamesa & & 0 & 0 & 0 & 0 & 0 & 48 & 224 & 160 & 0 & 0 & 0 & 0 & 0 & 1000 & 440 & 0 & 0 \\
\hline Pseudokiefferiella & & 0 & 0 & 0 & 0 & 0 & 0 & 0 & 0 & 0 & 0 & 0 & 0 & 0 & 0 & 0 & 0 & 3600 \\
\hline Boreoheptagyia & & 0 & 0 & 0 & 0 & 0 & 0 & 0 & 0 & 0 & 0 & 0 & 0 & 0 & 0 & 0 & 0 & 0 \\
\hline Orthocladiinae & & 0 & 20 & 0 & 0 & 0 & 768 & 272 & 16533 & 108480 & 21019 & 38859 & 5041 & 54400 & 1500 & 740 & 5653 & 80080 \\
\hline Chironominae & & 0 & 0 & 0 & 0 & 0 & 0 & 0 & 0 & 0 & 0 & 0 & 0 & 0 & 0 & 0 & 0 & 0 \\
\hline Tanytarsini & & 0 & 0 & 0 & 0 & 0 & 0 & 0 & 267 & 0 & 561 & 251 & 761 & 0 & 0 & 0 & 0 & 240 \\
\hline Chironomini & & 0 & 0 & 0 & 0 & 0 & 0 & 0 & 0 & 0 & 0 & 0 & 0 & 0 & 0 & 0 & 0 & 0 \\
\hline Tanypodinae & & 0 & 0 & 0 & 0 & 0 & 0 & 0 & 0 & 0 & 0 & 0 & 95 & 0 & 0 & 0 & 0 & 0 \\
\hline Psychodidae & & 0 & 0 & 0 & 0 & 0 & 0 & 0 & 0 & 0 & 0 & 0 & 0 & 0 & 0 & 0 & 0 & 0 \\
\hline Blephariceridae & & 0 & 0 & 0 & 0 & 0 & 0 & 0 & 0 & 0 & 0 & 0 & 0 & 0 & 0 & 0 & 0 & 0 \\
\hline Empididae & & 0 & 32 & 0 & 0 & 0 & 48 & 0 & 0 & 80 & 0 & 0 & 0 & 0 & 0 & 0 & 27 & 320 \\
\hline Dolichopodidae & & 0 & 0 & 0 & 0 & 0 & 0 & 0 & 0 & 0 & 0 & 0 & 0 & 0 & 0 & 0 & 0 & 0 \\
\hline Muscidae (Lispe) & & 0 & 0 & 0 & 0 & 0 & 0 & 0 & 107 & 400 & 0 & 0 & 0 & 480 & 0 & 0 & 53 & 0 \\
\hline Dixidae & & 0 & 0 & 0 & 0 & 0 & 0 & 0 & 0 & 0 & 0 & 0 & 40 & 160 & 0 & 0 & 0 & 0 \\
\hline Thaumaleidae & & 0 & 0 & 0 & 0 & 0 & 0 & 0 & 0 & 0 & 0 & 0 & 0 & 0 & 0 & 0 & 0 & 0 \\
\hline \multicolumn{19}{|c|}{ MOLLUSCA - Planorbidae } \\
\hline Gyraulus & & 0 & 0 & 0 & 0 & 0 & 0 & 0 & 0 & 0 & 40 & 80 & 0 & 0 & 0 & 0 & 0 & 0 \\
\hline
\end{tabular}





\begin{tabular}{|c|c|c|c|c|c|c|c|c|c|c|c|c|c|c|c|c|}
\hline \multirow[b]{2}{*}{$\begin{array}{l}\text { microhabitat } \\
\mathrm{n}^{\circ} \text { replicates }\end{array}$} & \multicolumn{10}{|c|}{ June 2018} & \multicolumn{6}{|c|}{ August 2018} \\
\hline & $\begin{array}{c}\mathbf{Z 1} \\
\min \\
5\end{array}$ & $\begin{array}{c}\mathbf{Z 3} \\
\min \\
4\end{array}$ & $\begin{array}{c}\mathbf{Z 3} \\
\text { mos } \\
1\end{array}$ & $\begin{array}{c}\mathrm{Z4} \\
\min \\
4\end{array}$ & $\begin{array}{c}\text { Z4 } \\
\text { Hyd } \\
1\end{array}$ & $\begin{array}{c}\mathbf{Z 5} \\
\min \\
5\end{array}$ & $\begin{array}{c}\mathbf{z 7} \\
\min \\
3\end{array}$ & $\begin{array}{c}\mathbf{Z 7} \\
\mathrm{mos} \\
2\end{array}$ & $\begin{array}{c}\mathbf{Z 1 2} \\
\min \\
3\end{array}$ & $\begin{array}{c}\mathrm{Z12} \\
\mathrm{mos} \\
2\end{array}$ & $\begin{array}{c}\mathrm{Z3} \\
\min \\
4\end{array}$ & $\begin{array}{c}\mathrm{Z3} \\
\mathrm{mos} \\
1\end{array}$ & $\begin{array}{c}\mathbf{Z 4} \\
\min \\
5\end{array}$ & $\begin{array}{c}\mathbf{Z 5} \\
\min \\
5\end{array}$ & $\begin{array}{c}\mathrm{Z12} \\
\min \\
4\end{array}$ & $\begin{array}{c}\mathbf{Z 1 2} \\
\text { mos } \\
1\end{array}$ \\
\hline \multicolumn{17}{|l|}{ TURBELLARIA } \\
\hline Crenobia alpina (Dana, 1766) & 0 & 0 & 0 & 0 & 0 & 0 & 0 & 0 & 20 & 0 & 0 & 0 & 0 & 0 & 0 & 0 \\
\hline NEMATODA & 0 & 0 & 800 & 200 & 0 & 1120 & 427 & 2400 & 2400 & 3200 & 50 & 0 & 0 & 160 & 2000 & 1040 \\
\hline \multicolumn{17}{|l|}{ OLIGOCHAETA } \\
\hline Lumbriculidae & 0 & 0 & 0 & 0 & 0 & 0 & 0 & 0 & 0 & 0 & 0 & 0 & 0 & 0 & 0 & 0 \\
\hline Haplotaxidae & 0 & 0 & 0 & 0 & 0 & 16 & 0 & 320 & 0 & 0 & 0 & 0 & 0 & 0 & 0 & 0 \\
\hline Enchytraeidae & 0 & 0 & 0 & 20 & 0 & 176 & 533 & 1360 & 360 & 1920 & 20 & 0 & 0 & 32 & 180 & 320 \\
\hline Naididae & 0 & 0 & 0 & 0 & 0 & 0 & 7200 & 16000 & 0 & 0 & 0 & 0 & 0 & 0 & 0 & 0 \\
\hline TARDIGRADA & 0 & 0 & 160 & 0 & 0 & 0 & 0 & 240 & 20 & 720 & 0 & 0 & 0 & 0 & 0 & 0 \\
\hline HYDRACHNIDIA & 0 & 0 & 0 & 60 & 0 & 0 & 0 & 400 & 20 & 160 & 20 & 0 & 0 & 0 & 80 & 0 \\
\hline \multicolumn{17}{|l|}{ CRUSTACEA } \\
\hline Ostracoda & 0 & 0 & 0 & 0 & 0 & 496 & 0 & 0 & 180 & 160 & 0 & 0 & 0 & 32 & 660 & 80 \\
\hline Copepoda & 0 & 0 & 0 & 20 & 0 & 256 & 80 & 160 & 60 & 0 & 60 & 0 & 0 & 32 & 0 & 80 \\
\hline COLLEMBOLA & 8 & 0 & 0 & 40 & 0 & 16 & 0 & 0 & 0 & 0 & 20 & 0 & 0 & 32 & 60 & 320 \\
\hline \multicolumn{17}{|l|}{ EPHEMEROPTERA } \\
\hline \multicolumn{17}{|l|}{ Heptagenidae } \\
\hline Rhithrogena juv & 0 & 0 & 0 & 0 & 0 & 0 & 0 & 0 & 40 & 0 & 0 & 0 & 0 & 0 & 0 & 0 \\
\hline Rhithrogena sp. & 0 & 0 & 0 & 0 & 0 & 0 & 0 & 0 & 0 & 0 & 0 & 0 & 0 & 0 & 0 & 0 \\
\hline Rhitrogena loyolaea Navàs, 1922 & 0 & 0 & 0 & 0 & 0 & 0 & 80 & 0 & 60 & 0 & 0 & 0 & 20 & 16 & 60 & 0 \\
\hline \multicolumn{16}{|l|}{ Baetidae } & 0 \\
\hline Baetis alpinus (Pictet, 1834) & 0 & 0 & 0 & 0 & 0 & 0 & 987 & 2000 & 1100 & 1120 & 0 & 0 & 0 & 16 & 920 & 720 \\
\hline \multicolumn{17}{|l|}{ PLECOPTERA } \\
\hline Plecoptera juv & 0 & 0 & 0 & 0 & 0 & 0 & 0 & 0 & 580 & 720 & 0 & 0 & 0 & 0 & 60 & 2000 \\
\hline \multicolumn{17}{|l|}{ Perlodidae } \\
\hline Dictyogenus fontium (Ris, 1896) & 0 & 0 & 0 & 0 & 0 & 0 & 27 & 0 & 100 & 0 & 0 & 0 & 0 & 64 & 1140 & 3680 \\
\hline Isoperla cf. rivulorum (Pictet, 1841) & 0 & 0 & 0 & 0 & 0 & 0 & 0 & 0 & 580 & 720 & 0 & 0 & 0 & 0 & 100 & 640 \\
\hline Chloroperlidae & & & & & & & & & & & & & & & & \\
\hline
\end{tabular}




\begin{tabular}{|c|c|c|c|c|c|c|c|c|c|c|c|c|c|c|c|c|}
\hline $\begin{array}{l}\text { Chloroperla susemicheli Zwick, } 1967 \\
\text { Taeniopterygidae }\end{array}$ & 0 & 0 & 0 & 0 & 0 & 0 & 0 & 0 & 0 & 0 & 0 & 0 & 0 & 0 & 20 & 0 \\
\hline $\begin{array}{l}\text { Rhabdiopteryx alpina Kühtreiber, } 1934 \\
\text { Nemouridae }\end{array}$ & 0 & 0 & 0 & 0 & 0 & 0 & 0 & 0 & 0 & 0 & 0 & 0 & 0 & 0 & 0 & 0 \\
\hline Protonemura sp. & 0 & 0 & 0 & 20 & 0 & 0 & 0 & 0 & 40 & 80 & 0 & 0 & 0 & 0 & 100 & 80 \\
\hline & \multicolumn{10}{|c|}{ June 2018} & \multicolumn{6}{|c|}{ August 2018} \\
\hline & $\mathrm{Z1}$ & $\mathrm{Z3}$ & $\mathrm{Z3}$ & $\mathrm{Z4}$ & $\mathrm{Z4}$ & $\mathrm{Z5}$ & $\mathbf{Z 7}$ & $\mathbf{Z 7}$ & $\mathrm{Z12}$ & $\mathrm{Z12}$ & $\mathrm{Z3}$ & $\mathbf{Z 3}$ & $\mathbf{Z 4}$ & $\mathbf{Z 5}$ & $\mathrm{Z12}$ & $\mathrm{Z12}$ \\
\hline microhabitat & $\min$ & $\min$ & mos & $\min$ & Hyd & $\min$ & $\min$ & mos & $\min$ & mos & $\min$ & mos & $\min$ & $\min$ & $\min$ & mos \\
\hline $\mathrm{n}^{\circ}$ replicates & 5 & 4 & 1 & 4 & 1 & 5 & 3 & 2 & 3 & 2 & 4 & 1 & 5 & 5 & 4 & 1 \\
\hline Protonemura brevistyla (Ris, 1902) & 0 & 0 & 0 & 0 & 0 & 0 & 0 & 0 & 80 & 0 & 0 & 0 & 0 & 0 & 20 & 240 \\
\hline Protonemura nitida (Pictet, 1835) & 0 & 0 & 0 & 0 & 0 & 0 & 53 & 0 & 100 & 800 & 0 & 0 & 0 & 0 & 40 & 0 \\
\hline Protonemura cf. lateralis (Pictet, 1835) & 0 & 0 & 0 & 0 & 0 & 16 & 80 & 640 & 0 & 1280 & 0 & 0 & 0 & 16 & 20 & 240 \\
\hline Protonemura nimborum (Ris, 1902) & 0 & 0 & 0 & 0 & 0 & 0 & 0 & 0 & 0 & 0 & 0 & 0 & 0 & 0 & 0 & 0 \\
\hline Proronemura cf. caprai (Aubert, 1954) & 0 & 0 & 0 & 0 & 0 & 0 & 0 & 0 & 0 & 0 & 0 & 0 & 0 & 0 & 20 & 0 \\
\hline Nemoura mortoni (Ris, 1902) & 0 & 0 & 0 & 0 & 0 & 0 & 27 & 0 & 220 & 240 & 0 & 0 & 0 & 0 & 300 & 0 \\
\hline Leuctridae & 0 & 0 & 0 & 0 & 0 & 0 & 0 & 0 & 0 & 0 & 0 & 0 & 0 & 0 & 80 & 0 \\
\hline Leuctridae/Capnidae & 0 & 0 & 0 & 0 & 0 & 0 & 0 & 0 & 0 & 0 & 0 & 0 & 0 & 0 & 80 & 0 \\
\hline Leuctra major Brink, 1949 & 0 & 0 & 0 & 0 & 0 & 0 & 0 & 0 & 0 & 0 & 0 & 0 & 0 & 0 & 0 & 0 \\
\hline Leuctra rosinae Kempny, 1900 & 0 & 0 & 0 & 0 & 0 & 0 & 0 & 0 & 100 & 80 & 0 & 0 & 0 & 0 & 40 & 0 \\
\hline Leuctra cf. teriolensis Kempny, 1900 & 0 & 0 & 0 & 0 & 0 & 0 & 0 & 0 & 0 & 80 & 0 & 0 & 0 & 0 & 0 & 0 \\
\hline Leuctra braueri Kempny, 1898 & 0 & 0 & 0 & 0 & 0 & 0 & 0 & 0 & 40 & 0 & 0 & 0 & 0 & 0 & 40 & 0 \\
\hline THYSANOPTERA & 0 & 0 & 0 & 400 & 0 & 0 & 0 & 0 & 0 & 0 & 20 & 0 & 0 & 0 & 20 & 0 \\
\hline \multicolumn{17}{|l|}{ TRICHOPTERA } \\
\hline \multicolumn{17}{|l|}{ Rhyacophilidae } \\
\hline Rhyacophila intermedia McLachlan, 1868 & 0 & 0 & 0 & 0 & 0 & 0 & 0 & 0 & 0 & 0 & 0 & 0 & 0 & 0 & 0 & 0 \\
\hline Rhyacophila pubescens Pictet, 1834 & 0 & 0 & 0 & 0 & 0 & 0 & 0 & 0 & 0 & 0 & 0 & 0 & 0 & 0 & 0 & 0 \\
\hline Limpnephilidae & 0 & 0 & 0 & 0 & 0 & 0 & 0 & 0 & 0 & 0 & 0 & 0 & 0 & 0 & 0 & 0 \\
\hline Drusus monticola (McLachlan, 1867) & 0 & 0 & 0 & 0 & 0 & 0 & 0 & 0 & 0 & 0 & 0 & 0 & 0 & 0 & 0 & 0 \\
\hline Drusus cf. adustus (McLachlan, 1867) & 0 & 0 & 0 & 0 & 0 & 0 & 53 & 0 & 0 & 0 & 0 & 0 & 40 & 0 & 0 & 0 \\
\hline Acrophylax zerberus Brauer, 1867 & 0 & 0 & 0 & 120 & 2080 & 336 & 80 & 560 & 60 & 0 & 0 & 0 & 240 & 208 & 20 & 80 \\
\hline Micropterna lateralis (Stephens, 1837) & 0 & 0 & 0 & 0 & 0 & 0 & 0 & 0 & 40 & 400 & 0 & 0 & 0 & 0 & 0 & 0 \\
\hline Drusus discolor (Rambur, 1842) & 0 & 0 & 0 & 0 & 0 & 0 & 0 & 0 & 0 & 9600 & 0 & 0 & 0 & 0 & 1140 & 4400 \\
\hline
\end{tabular}


Goeridae

Lithax niger (Hagen, 1859)

COLEOPTERA

Coleoptera

Elminthidae

DIPTERA

Tipulidae

Limoniidae

Pediciidae

Simuliidae

June 2018

$\begin{array}{llll}\mathbf{Z 1} & \mathbf{Z 3} & \mathbf{Z 3} & \mathbf{Z 4}\end{array}$

Z4 Z5 Z7

27

$n^{\circ}$ replicates

$\begin{array}{cccc}\min & \min & \operatorname{mos} & \min \\ 5 & 4 & 1 & 4 \\ 0 & 0 & 0 & 0\end{array}$

Ceratopogonida

Chironomidae

\section{Diamesinae}

Diamesa

Pseudodiamesa

Pseudokiefferiella

Boreoheptagyia

Orthocladiinae

Chironominae

Tanytarsini

Chironomini

\section{Tanypodinae}

Psychodidae

Blephariceridae

Empididae

Dolichopodidae

Muscidae (Lispe)

Dixidae

\begin{tabular}{cccccccccc|cccccc}
152 & 280 & 1920 & 80360 & 97600 & 1600 & 3793 & 0 & 462 & 0 & 4490 & 19680 & 2240 & 96 & 0 & 0 \\
0 & 0 & 0 & 0 & 0 & 0 & 0 & 0 & 0 & 0 & 0 & 0 & 0 & 128 & 0 & 0 \\
0 & 0 & 0 & 0 & 0 & 0 & 1517 & 21718 & 346 & 17488 & 0 & 0 & 0 & 0 & 99 & 6240 \\
0 & 0 & 0 & 0 & 0 & 0 & 0 & 0 & 0 & 0 & 0 & 0 & 0 & 0 & 0 & 0 \\
0 & 20 & 3360 & 10040 & 0 & 112 & 9861 & 65154 & 1269 & 41972 & 470 & 0 & 60 & 1120 & 8903 & 57600 \\
0 & 0 & 0 & 0 & 0 & 0 & 0 & 0 & 0 & 0 & 0 & 0 & 0 & 0 & 0 & 0 \\
0 & 0 & 0 & 0 & 0 & 0 & 455 & 1448 & 20 & 720 & 0 & 0 & 0 & 0 & 198 & 0 \\
0 & 0 & 0 & 0 & 0 & 0 & 0 & 0 & 0 & 0 & 0 & 0 & 0 & 0 & 0 & 0 \\
0 & 0 & 0 & 0 & 0 & 0 & 0 & 0 & 0 & 0 & 0 & 0 & 0 & 0 & 0 & 0 \\
0 & 0 & 0 & 0 & 0 & 0 & 0 & 0 & 0 & 160 & 0 & 0 & 0 & 0 & 0 & 0 \\
0 & 0 & 0 & 0 & 0 & 0 & 0 & 0 & 20 & 0 & 0 & 0 & 0 & 0 & 0 & 0 \\
0 & 0 & 0 & 0 & 0 & 0 & 0 & 80 & 0 & 0 & 0 & 0 & 0 & 0 & 60 & 0 \\
0 & 0 & 0 & 0 & 0 & 0 & 0 & 0 & 0 & 0 & 0 & 0 & 0 & 0 & 0 & 0 \\
0 & 0 & 0 & 0 & 0 & 0 & 0 & 0 & 0 & 0 & 0 & 0 & 0 & 0 & 0 & 0 \\
0 & 0 & 0 & 0 & 0 & 0 & 0 & 0 & 20 & 0 & 0 & 0 & 0 & 0 & 0 & 0
\end{tabular}


Thaumaleidae

MOLLUSCA - Planorbidae

Gyraulus
$0 \quad 0 \quad 0 \quad 0$

\begin{tabular}{ll|l}
0 & 0 & 0 \\
0 & 0 & 0
\end{tabular}




\begin{tabular}{|c|c|c|c|c|c|c|}
\hline $\begin{array}{r}\text { station } \\
\text { microhabitat } \\
\mathrm{n}^{\circ} \text { replicates } \\
\end{array}$ & $\begin{array}{c}\text { Z12 } \\
\min \\
4 \\
\end{array}$ & $\begin{array}{c}\mathbf{Z 1 2} \\
\mathrm{mos} \\
1 \\
\end{array}$ & $\begin{array}{c}\text { ZRG } \\
\min \\
3 \\
\end{array}$ & $\begin{array}{c}\text { ZRG } \\
\text { san } \\
2 \\
\end{array}$ & $\begin{array}{c}\text { SRG } \\
\min \\
3 \\
\end{array}$ & $\begin{array}{c}\text { SRG } \\
\text { mos } \\
2 \\
\end{array}$ \\
\hline \multicolumn{7}{|l|}{ TURBELLARIA } \\
\hline Crenobia alpina (Dana, 1766) & 0 & 0 & 0 & 0 & 0 & 0 \\
\hline NEMATODA & 80 & 1600 & 0 & 0 & 480 & 480 \\
\hline \multicolumn{7}{|l|}{ OLIGOCHAETA } \\
\hline Lumbriculidae & 0 & 0 & 0 & 0 & 0 & 0 \\
\hline Haplotaxidae & 0 & 0 & 0 & 0 & 0 & 80 \\
\hline Enchytraeidae & 240 & 160 & 0 & 160 & 160 & 320 \\
\hline Naididae & 0 & 0 & 0 & 0 & 0 & 0 \\
\hline TARDIGRADA & 0 & 80 & 0 & 0 & 0 & 240 \\
\hline HYDRACHNIDIA & 60 & 240 & 0 & 240 & 53 & 400 \\
\hline \multicolumn{7}{|l|}{ CRUSTACEA } \\
\hline Ostracoda & 180 & 240 & 0 & 0 & 0 & 0 \\
\hline Copepoda & 0 & 400 & 480 & 0 & 0 & 80 \\
\hline COLLEMBOLA & 0 & 0 & 0 & 0 & 0 & 160 \\
\hline \multicolumn{7}{|l|}{ EPHEMEROPTERA } \\
\hline \multicolumn{7}{|l|}{ Heptagenidae } \\
\hline Rhithrogena & 0 & 0 & 0 & 0 & 0 & 0 \\
\hline Rhithrogena sp. & 0 & 0 & 0 & 0 & 0 & 0 \\
\hline Rhitrogena loyolaea Navàs, 1922 & 180 & 0 & 0 & 0 & 53 & 0 \\
\hline Rhitrogena gr. semicolorata & 0 & 0 & 0 & 0 & 0 & 0 \\
\hline \multicolumn{7}{|l|}{ Baetidae } \\
\hline Baetis alpinus (Pictet, 1834) & 80 & 2400 & 0 & 0 & 160 & 720 \\
\hline \multicolumn{7}{|l|}{ PLECOPTERA } \\
\hline Plecoptera juv & 80 & 400 & 0 & 0 & 0 & 0 \\
\hline \multicolumn{7}{|l|}{ Perlodidae } \\
\hline Dictyogenus fontium (Ris, 1896) & 1420 & 160 & 0 & 0 & 1760 & 80 \\
\hline Isoperla cf. rivulorum (Pictet, 1841) & 60 & 1600 & 0 & 0 & 107 & 0 \\
\hline \multicolumn{7}{|l|}{ Chloroperlidae } \\
\hline Chloroperla susemicheli Zwick, 1967 & 0 & 80 & 0 & 0 & 0 & 0 \\
\hline \multicolumn{7}{|l|}{ Taeniopterygidae } \\
\hline Rhabdiopteryx alpina Kühtreiber, 1934 & 0 & 0 & 0 & 0 & 2027 & 80 \\
\hline \multicolumn{7}{|l|}{ Nemouridae } \\
\hline Protonemura sp. & 0 & 160 & 0 & 0 & 0 & 0 \\
\hline Protonemura brevistyla (Ris, 1902) & 0 & 0 & 0 & 0 & 0 & 0 \\
\hline \multirow{4}{*}{$\begin{array}{l}\mathrm{n}{ }^{\circ} \text { replica } \\
\text { Protonemura nitida (Pictet, 1835) }\end{array}$} & $\mathrm{Z12}$ & $\mathrm{Z12}$ & ZRG & ZRG & SRG & SRG \\
\hline & $\min$ & mos & $\min$ & san & $\min$ & mos \\
\hline & 4 & 1 & 3 & 2 & 3 & 2 \\
\hline & 0 & 2560 & 0 & 0 & 0 & 0 \\
\hline Protonemura cf. lateralis (Pictet, 1835) & 20 & 160 & 0 & 0 & 0 & 0 \\
\hline Protonemura nimborum (Ris, 1902) & 0 & 0 & 0 & 0 & 0 & 0 \\
\hline Proronemura cf. caprai (Aubert, 1954) & 0 & 0 & 0 & 0 & 0 & 0 \\
\hline Nemoura mortoni (Ris, 1902) & 60 & 1440 & 0 & 0 & 53 & 0 \\
\hline Leuctridae & 0 & 0 & 0 & 0 & 0 & 0 \\
\hline Leuctridae/Capnidae & 0 & 0 & 0 & 0 & 0 & 0 \\
\hline Leuctra major Brink, 1949 & 0 & 0 & 0 & 0 & 0 & 0 \\
\hline Leuctra rosinae Kempny, 1900 & 80 & 160 & 0 & 0 & 1227 & 640 \\
\hline Leuctra cf. teriolensis Kempny, 1900 & 0 & 0 & 0 & 0 & 0 & 0 \\
\hline
\end{tabular}


Leuctra braueri Kempny, 1898

THYSANOPTERA

TRICHOPTERA

Rhyacophilidae

Rhyacophila intermedia McLachlan, 1868

Rhyacophila pubescens Pictet, 1834

Limpnephilidae

Drusus monticola (McLachlan, 1867)

Drusus cf. adustus (McLachlan, 1867)

Acrophylax zerberus Brauer, 1867

Micropterna lateralis (Stephens, 1837)

Drusus discolor (Rambur, 1842)

\section{Goeridae}

Lithax niger (Hagen, 1859)

\section{COLEOPTERA}

\section{Coleoptera}

Elminthidae

\section{DIPTERA}

Tipulidae

Limoniidae

Pediciidae

Simuliidae

Ceratopogonidae

Chironomidae

\begin{tabular}{|c|c|c|c|c|c|c|c|}
\hline September 2018 & $\begin{array}{r}\text { station } \\
\text { microhabitat } \\
\mathrm{n}^{\circ} \text { replicates }\end{array}$ & $\begin{array}{c}\mathrm{Z12} \\
\min \\
4\end{array}$ & $\begin{array}{c}\mathrm{Z12} \\
\text { mos } \\
1\end{array}$ & $\begin{array}{l}\text { ZRG } \\
\min \\
3\end{array}$ & $\begin{array}{c}\text { ZRG } \\
\text { san } \\
2\end{array}$ & $\begin{array}{c}\text { SRG } \\
\min \\
3\end{array}$ & $\begin{array}{l}\text { SRG } \\
\text { mos } \\
2\end{array}$ \\
\hline \multicolumn{8}{|l|}{ Diamesinae } \\
\hline Diamesa & & 0 & 0 & 80 & 80 & 373 & 5680 \\
\hline Pseudodiamesa & & 0 & 0 & 107 & 1200 & 0 & 560 \\
\hline Pseudokiefferiella & & 0 & 0 & 0 & 0 & 0 & 5680 \\
\hline Boreoheptagyia & & 0 & 0 & 0 & 0 & 0 & 0 \\
\hline Orthocladiinae & & 1720 & 57600 & 80 & 80 & 2187 & 31360 \\
\hline Chironominae & & 0 & 0 & 0 & 0 & 0 & 0 \\
\hline Tanytarsini & & 340 & 880 & 0 & 0 & 0 & 0 \\
\hline Chironomini & & 0 & 0 & 0 & 0 & 0 & 0 \\
\hline Tanypodinae & & 0 & 0 & 0 & 0 & 0 & 0 \\
\hline Psychodidae & & 60 & 240 & 0 & 0 & 0 & 0 \\
\hline Blephariceridae & & 0 & 0 & 0 & 0 & 0 & 0 \\
\hline Empididae & & 0 & 0 & 0 & 0 & 0 & 0 \\
\hline Dolichopodidae & & 0 & 0 & 0 & 0 & 0 & 0 \\
\hline Muscidae (Lispe) & & 100 & 80 & 0 & 0 & 0 & 0 \\
\hline Dixidae & & 0 & 0 & 0 & 0 & 0 & 0 \\
\hline Thaumaleidae & & 0 & 0 & 0 & 0 & 0 & 0 \\
\hline \multicolumn{8}{|c|}{ MOLLUSCA - Planorbidae } \\
\hline Gyraulus & & 0 & 0 & 0 & 0 & 0 & 0 \\
\hline
\end{tabular}

$\begin{array}{llllll}40 & 0 & 0 & 0 & 0 & 0 \\ 20 & 0 & 0 & 0 & 0 & 0\end{array}$

$\begin{array}{cccccc}0 & 0 & 0 & 0 & 0 & 0 \\ 0 & 0 & 0 & 0 & 0 & 0 \\ 0 & 0 & 0 & 0 & 0 & 0 \\ 0 & 0 & 0 & 0 & 0 & 0 \\ 0 & 0 & 0 & 0 & 1813 & 3360 \\ 500 & 9760 & 107 & 0 & 0 & 0 \\ 0 & 0 & 0 & 0 & 0 & 0 \\ 100 & 3600 & 0 & 0 & 0 & 0\end{array}$

$\begin{array}{llllll}0 & 0 & 0 & 0 & 0 & 0\end{array}$

$\begin{array}{llllll}0 & 0 & 0 & 0 & 0 & 0\end{array}$

$\begin{array}{llllll}0 & 0 & 0 & 0 & 0 & 0\end{array}$

$\begin{array}{llllll}0 & 0 & 0 & 0 & 0 & 0\end{array}$

$\begin{array}{llllll}0 & 0 & 0 & 0 & 0 & 0\end{array}$

$\begin{array}{llllll}100 & 0 & 0 & 0 & 53 & 160\end{array}$

$\begin{array}{llllll}0 & 80 & 0 & 0 & 53 & 0\end{array}$

$\begin{array}{llllll}0 & 0 & 0 & 0 & 0 & 0\end{array}$

$\begin{array}{llllll}0 & 0 & 0 & 0 & 0 & 0\end{array}$ 
Supplementary S2. Protocol for the assessment of BOM storage in the mineral substrate.

When comparing BOM from different microhabitats, the considerable amount of bryophyte fragments trapped among cobbles lead to a potential overestimation of the values associated to the mineral substrates. In order to offset such problem, we applied specifically-designed conversion factors when these microhabitats were compared. In particular, the BOM of the mineral microhabitat was adjusted by applying the following equation:

$$
\mathrm{BOM}_{\min }=\mathrm{BOM}_{\mathrm{raw}} * \% \min
$$

where $\mathrm{BOM}_{\min }$ is the storage capacity of the mineral substrate alone, $\mathrm{BOM}_{\text {raw }}$ the raw outcome from the laboratory analysis for the mineral microhabitat (both expressed as $\mathrm{g} \mathrm{m}^{-2}$ ), and \% min $_{\text {the }}$ percentage of detritus stored in the mineral fraction of the sample. The \%min was calculated as:

$$
\%_{\min }=\frac{\mathrm{CPOMmin}}{\mathrm{CPOMmin}+\mathrm{CPOMmos}}
$$

where $\mathrm{CPOM}_{\min }$ is the CPOM stored in the mineral fraction of the mineral microhabitat, $\mathrm{CPOM}_{\text {mos }}$ is the CPOM stored in the moss fragments trapped in the mineral fraction. These parameters were calculated only for the CPOM, given the practical limitations brought by the leaching of the fine fraction from bryophytes in the sample. 
Supplementary S3. Conversion factors for size-mass equations. Dry mass was obtained by applying the exponential equation $D M=a$ $L^{b}$, where $L$ is the body length (Méthot et al., 2012), a and b the conversion factors specific for each taxon.

\begin{tabular}{|c|c|c|c|c|c|}
\hline Taxon & a & b & reference & Taxon reference & notes \\
\hline Plecoptera juvenile & 0.0049 & 2.562 & Benke, Huryn, Smock \& Wallace, 1999 & Plecoptera & \\
\hline Dictyogenus fontium & 0.0067 & 2.695 & Zwick \& Zwick, 2010 & Dictyogenus fontium & \\
\hline Isoperla sp. & 0.0072 & 2.743 & Giustini, Miccoli, de Luca \& Cicolani, 2008 & Isoperla grammatica & \\
\hline Protonemoura sp. & 0.0056 & 2.762 & Benke et al., 1999 & Nemouridae & \\
\hline Nemoura sp. & 0.0019 & 3.588 & Giustini et al., 2008 & Nemoura cinerea & \\
\hline Leuctra sp. & 0.0027 & 2.818 & Giustini et al., 2008 & Leuctra sp & \\
\hline Rhabdiopteryx alpina & 0.0072 & 2.655 & Benke et al., 1999 & Taeniopterygidae & \\
\hline Baetis alpinus & 0.0100 & 2.550 & Breitenmoser-Würsten \& Sartori, 1995 & Baetis alpinus & \\
\hline Rhithrogena sp. & 0.0138 & 2.560 & Breitenmoser-Würsten \& Sartori, 1995 & Rhithrogena sp & \\
\hline Limnephilidae & 0.0040 & 2.933 & Benke et al., 1999 & Limnephilidae & \\
\hline Goeridae & 0.0040 & 2.933 & Benke et al., 1999 & Goeridae & \\
\hline Rhyacophilidae & 0.0099 & 2.480 & Benke et al., 1999 & Rhyacophilidae & \\
\hline Ceratopogonidae & 0.0025 & 2.469 & Benke et al., 1999 & Ceratopogonidae & \\
\hline Chironomidae & 0.0018 & 2.617 & Benke et al., 1999 & Chironomidae & Other stations \\
\hline Chironomidae & 0.0021 & 2.803 & Nolte, 1990 & Diamesa sp & Only kryal \\
\hline Chironomidae & 0.0007 & 2.736 & Nolte, 1990 & Micropsectra sp & SRG: most specimens very slim \\
\hline Blephariceridae & 3.292 & 0.0067 & Benke et al., 1999 & Blephariceridae & \\
\hline Dolichopodidae & 0.0054 & 2.546 & Benke et al., 1999 & Empididae & Not found in literature \\
\hline Dixidae & 0.0018 & 2.617 & Benke et al., 1999 & Chironomidae & Not found in literature \\
\hline Empididae & 0.0054 & 2.546 & Benke et al., 1999 & Empididae & Not found in literature \\
\hline Limoniidae & 0.0054 & 2.546 & Benke et al., 1999 & Empididae & Not found in literature \\
\hline Pediciidae & 0.0054 & 2.546 & Benke et al., 1999 & Empididae & Not found in literature \\
\hline Muscidae & 0.0054 & 2.546 & Benke et al., 1999 & Empididae & Not found in literature \\
\hline Psychodidae & 0.0018 & 2.617 & Benke et al., 1999 & Chironomidae & Not found in literature \\
\hline Simuliidae & 0.002 & 3.011 & Benke et al., 1999 & Simuliidae & \\
\hline Thaumaleidae & 0.0018 & 2.617 & Benke et al., 1999 & Chironomidae & Not found in literature \\
\hline Tipulidae & 0.0054 & 2.546 & Benke et al., 1999 & Empidiidae & Not found in literature \\
\hline Elminthidae & 0.0074 & 2.879 & Benke et al., 1999 & Elminthidae & \\
\hline Gyraulus sp. & 0.9608 & 2.650 & Mèthot et al., 2012 & Planorbidae & \\
\hline Lumbriculidae & 0.1075 & 1.540 & Mèthot et al., 2012 & Oligochaeta & \\
\hline Enchytraeidae & 0.1075 & 1.540 & Mèthot et al., 2012 & Oligochaeta & \\
\hline Haplotaxidae & 0.1075 & 1.540 & Mèthot et al., 2012 & Oligochaeta & \\
\hline Naididae & 0.1075 & 1.540 & Mèthot et al., 2012 & Oligochaeta & \\
\hline Crenobia & 0.0082 & 2.168 & Benke et al., 1999 & Turbellaria & \\
\hline
\end{tabular}


Supplementary S4. Linear mixed-effects models performed and associated results. For each of the models, we list: the "full" against the "null" model (response variable fixed effects), and the $\mathrm{df}, \chi^{2}$ and $p$-value resulting from their comparison (ANOVA), the intercept and estimate values of the fixed effects and the standard deviation explained by the random effects and residual. Where two random effects were present, they were crossed. Cross-comparisons between the effects are not displayed. Estimate values of months (Jun=June, Sep=September) are listed in the comparison with August, stream types in the comparison with glacio-rhithral, and the microhabitat "moss" (i.e. bryophyte mats) is compared with mineral substrate.

${ }^{1}$ we list only those taxa that show differences of body mass between mineral and moss substrates and the corresponding estimated effect; note that only taxa with a sufficient number of samples (>10) and density (>20 ind $\mathrm{m}^{-2}$ ) were used for the analyses, and only those with an estimate value $>|0.3|$ are displayed. Hydrurus foetidus was excluded from the analyses due to the low number of cases $(\mathrm{N}=3)$. 


\begin{tabular}{|c|c|c|c|c|c|c|}
\hline Model & Full model & Null model & $\begin{array}{l}(d f) \chi^{2} \\
p \text {-value }\end{array}$ & Int. & Fixed effects estimate & $\begin{array}{l}\text { Random effect(s) } \\
\text { SD }\end{array}$ \\
\hline Mildness & $\begin{array}{l}\text { Index Stream type * } \\
\text { Month }\end{array}$ & Index $\sim$ Stream type & $\begin{array}{l}(10) 18.92, \\
0.04\end{array}$ & 2.14 & $\begin{array}{l}\text { Jun= }-0.28 ; \text { Sep }=-0.39 \\
\text { Upper kryal= }-1.81 ; \text { Lower kryal= }-1.14 ; \\
\text { Krenal= }-0.06 ; \text { Rock glacial }=-0.79\end{array}$ & $\begin{array}{l}\text { Station }=0.35 \\
\text { Residual }=0.19\end{array}$ \\
\hline Chl- $a$ & $\begin{array}{l}\text { Chl- } a^{\log } \sim \text { Stream type } * \\
\text { month }\end{array}$ & Chl- $a^{\log } \sim$ Stream type & $\begin{array}{l}(10) 16.18 \\
0.09\end{array}$ & -0.24 & $\begin{array}{l}\text { Jun= 0.59; Sep=0.59 } \\
\text { Upper kryal= }-2.28 ; \text { Lower kryal=0.91; } \\
\text { Krenal= }-1.38 ; \text { Rock glacial }=-0.06\end{array}$ & $\begin{array}{l}\text { Station }=0.72 \\
\text { Residual }=0.73\end{array}$ \\
\hline Epilithic & $\begin{array}{l}\text { AFDM }^{\log \sim} \text { Stream type } \\
\text { month }\end{array}$ & $\begin{array}{l}\text { AFDM }{ }^{\log } \sim \text { Stream } \\
\text { type }\end{array}$ & $\begin{array}{l}(10) 28.0 \\
0.002\end{array}$ & 2.09 & $\begin{array}{l}\text { Jun=0.33; Sep=1.30 } \\
\text { Upper kryal= }-0.15 ; \text { Lower kryal }=0.13 ; \\
\text { Krenal= } 0.19 ; \text { Rock glacial }=-0.15\end{array}$ & $\begin{array}{l}\text { Station }=0 \\
\text { Residual }=0.78\end{array}$ \\
\hline $\begin{array}{l}\text { Benthic organic } \\
\text { matter }\end{array}$ & $\begin{array}{l}\text { BOM }^{\log } \sim \text { Microhabitat } * \\
\text { stream type }\end{array}$ & $\begin{array}{l}\text { BOM }^{\log } \sim \\
\text { Microhabitat }\end{array}$ & $\begin{array}{l}\text { (8) } 48.3 \\
<0.001\end{array}$ & 0.59 & $\begin{array}{l}\text { Moss }=0.62 \\
\text { Upper kryal= }-0.25 \text {; Lower kryal=0; Krenal= } \\
0.23 ; \text { Rock glacial= } 0.24\end{array}$ & $\begin{array}{l}\text { Station }=0.09 \\
\text { Residual }=0.21\end{array}$ \\
\hline $\begin{array}{l}\text { Invertebrate } \\
\text { Biomass }\end{array}$ & $\begin{array}{l}\text { Biomass }{ }^{\log } \sim \\
\text { Microhabitat * stream } \\
\text { type }\end{array}$ & $\begin{array}{l}\text { Biomasss }^{\log } \sim \\
\text { Microhabitat }\end{array}$ & $\begin{array}{l}\text { (8) } 20.4 \\
0.009\end{array}$ & 3.41 & $\begin{array}{l}\text { Moss }=0.24 \\
\text { Upper kryal= }-1.23 ; \text { Lower kryal= }-0.46 ; \\
\text { Krenal= }-0.48 ; \text { Rock glacial }=-0.59\end{array}$ & $\begin{array}{l}\text { Station }=0 \\
\text { Residual }=0.37\end{array}$ \\
\hline Abundance & $\begin{array}{l}\text { Abundance }{ }^{\log } \sim \\
\text { Microhabitat } * \text { stream } \\
\text { type }\end{array}$ & $\begin{array}{l}\text { Abundance }{ }^{\log } \sim \\
\text { Microhabitat }\end{array}$ & $\begin{array}{l}\text { (8) } 15.7 \\
0.046\end{array}$ & 4.33 & $\begin{array}{l}\text { Moss }=0.65 \\
\text { Upper kryal= }-1.19 ; \text { Lower kryal= }-0.39 ; \\
\text { Krenal= } 0.08 ; \text { Rock glacial= }-0.61\end{array}$ & $\begin{array}{l}\text { Station }=0.15 \\
\text { Residual }=0.34\end{array}$ \\
\hline $\begin{array}{l}\text { Invertebrate } \\
\text { Biomass }\end{array}$ & $\begin{array}{l}\text { Biomass }^{\log } \sim \mathrm{BOM}^{\log }+ \\
\text { Turbidity }^{\log }\end{array}$ & Biomass $^{\log } \sim$ BOM ${ }^{\log }$ & $\begin{array}{l}(1) 4.7 \\
0.03\end{array}$ & 2.59 & $\begin{array}{l}\text { Turbidity= }-0.29 \\
\mathrm{BOM}=0.14\end{array}$ & $\begin{array}{l}\text { Station }=0.60 \\
\text { Residual }=0.54\end{array}$ \\
\hline Body mass & $\begin{array}{l}\text { Body mass }{ }^{\log } \sim \\
\text { Microhabitat }+ \text { stream } \\
\text { type }\end{array}$ & $\begin{array}{l}\text { Body mass }{ }^{\log } \text { } \\
\text { Microhabitat }\end{array}$ & $\begin{array}{l}\text { (8) } 10.4 \\
0.24\end{array}$ & 4.9 & $\begin{array}{l}\text { Moss }=-0.14 \\
\text { Upper kryal= } 0.78 ; \text { Lower kryal }=0.30 \\
\text { Krenal= }-1.04 ; \text { Rock glacial }=-0.21\end{array}$ & $\begin{array}{l}\text { Station }=0.72 \\
\text { Taxon }=1.55 \\
\text { Residual }=1.30\end{array}$ \\
\hline
\end{tabular}




\begin{tabular}{|c|c|c|c|c|c|c|}
\hline Body mass & $\begin{array}{l}\text { Body mass }{ }^{\log } \sim \text { Taxon * } \\
\text { microhabitat }\end{array}$ & Body mass ${ }^{\log } \sim$ Taxon & $\begin{array}{l}(27) 30.4 \\
0.30\end{array}$ & 5.87 & $\begin{array}{l}\text { Moss }=-0.22 \\
{ }^{1} \text { Baetis }=-0.34 ; \text { Dictyogenus }=-0.48 ; \\
\text { Plecoptera juveniles= }-0.82 ; \text { Goeridae }=-0.52 ; \\
\text { Protonemura }=0.61 ; \text { Rhithrogena }=-1.90 ; \\
\text { Rhabdiopteryx }=0.48 ; \text { Enchytraeidae }=0.44\end{array}$ & $\begin{array}{l}\text { Station }=0.62 \\
\text { Residual }=1.17\end{array}$ \\
\hline $\begin{array}{l}\text { Collectors } \\
\text { abundance }\end{array}$ & $\begin{array}{l}\text { Collectors }{ }^{\log } \sim \\
\text { Microhabitat } * \text { stream } \\
\text { type }\end{array}$ & $\begin{array}{l}\text { Collectors }{ }^{\log } \text { } \\
\text { Microhabitat }\end{array}$ & $\begin{array}{l}(4) 22.76 \\
0.06\end{array}$ & 7.11 & $\begin{array}{l}\text { Moss }=1.47 \\
\text { Upper kryal= }-7.20 ; \text { Lower kryal= }-3.27 \\
\text { Krenal= } 0.14 ; \text { Rock glacial= }-1.59\end{array}$ & $\begin{array}{l}\text { Station=1.11 } \\
\text { Residual }=1.44\end{array}$ \\
\hline $\begin{array}{l}\text { Collectors } \\
\text { biomass }\end{array}$ & $\begin{array}{l}\text { Collectors }{ }^{\log } \sim \\
\text { Microhabitat } * \text { stream } \\
\text { type }\end{array}$ & $\begin{array}{l}\text { Collectors }{ }^{\log } \sim \\
\text { Microhabitat }\end{array}$ & $\begin{array}{l}(4) 29.39 \\
0.009\end{array}$ & 6.96 & $\begin{array}{l}\text { Moss= } 1.22 \\
\text { Upper kryal= }-5.41 ; \text { Lower kryal= }-3.51 ; \\
\text { Krenal= }-1.39 ; \text { Rock glacial= }-1.65\end{array}$ & $\begin{array}{l}\text { Station }=0 \\
\text { Residual }=1.14\end{array}$ \\
\hline
\end{tabular}


Supplementary S5. Boxplots of the average body mass ( $\mathrm{mg} \mathrm{ind}^{-1}$ of dry mass) of the most abundant taxa for each sampling station. Taxa belonging to the same order/family and with a similar size pattern were pooled together. Samples with a low number of specimens $\left(<20\right.$ ind $\left.\mathrm{m}^{-2}\right)$ were discarded. One outlier omitted from the Chironomidae boxplot, corresponding to ZRG station $\left(0.37 \mathrm{mg} \mathrm{ind}^{-1}\right)$. Oligochaeta only include Enchytraeidae and Naididae because of the low abundance of Haplotaxidae. Stations are highlighted according to habitat type: upper kryal=white, lower kryal= grey, glacio-rhithral= red, krenal= green, rock glacial= brown.
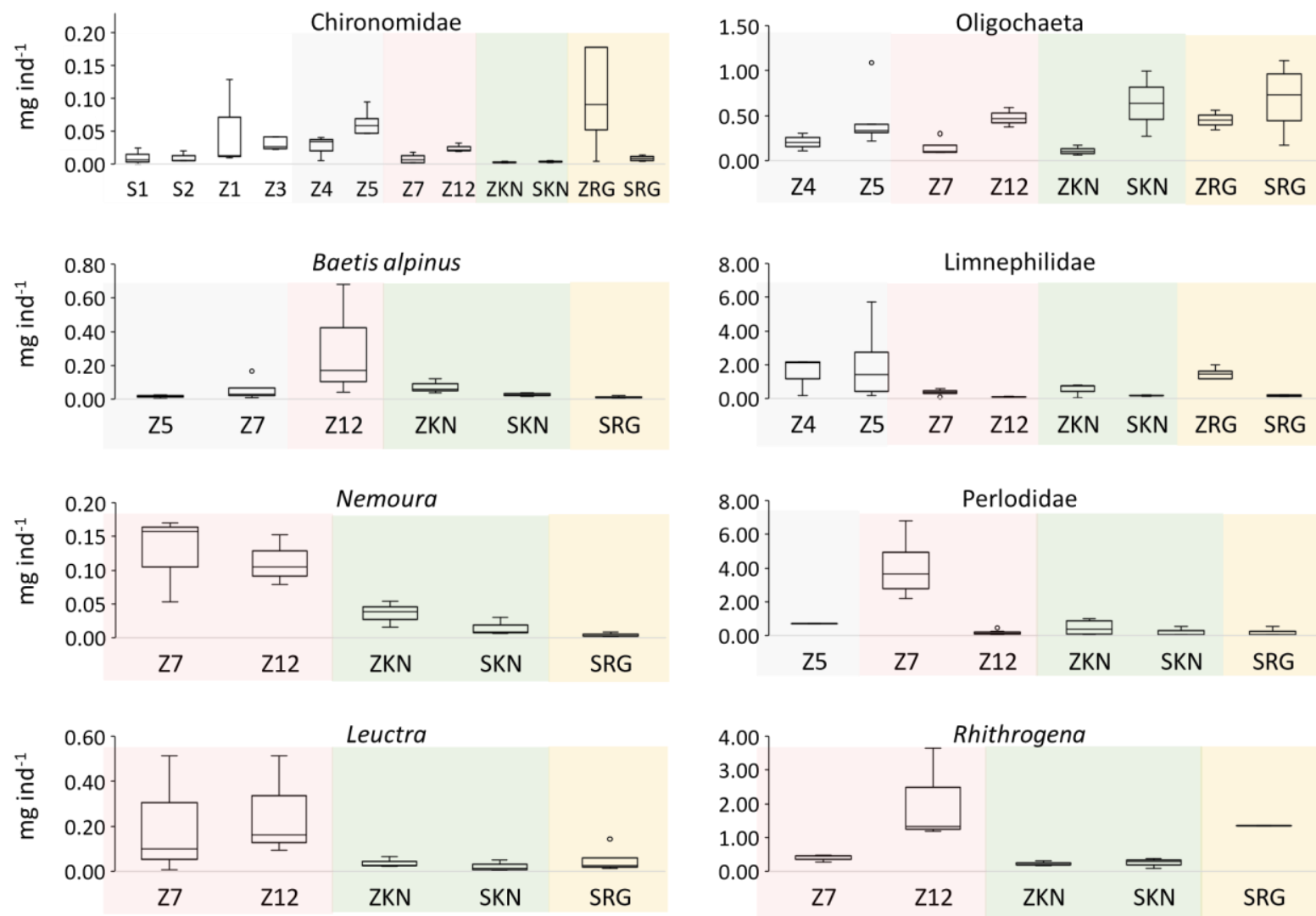